\title{
LEVEL II SCOUR ANALYSIS FOR BRIDGE 12 (HUNTTH00010012) on TOWN HIGHWAY 1, crossing BRUSH BROOK, HUNTINGTON, VERMONT
}

U.S. Geological Survey Open-File Report 97-226

Prepared in cooperation with

VERMONT AGENCY OF TRANSPORTATION and

FEDERAL HIGHWAY ADMINISTRATION 


\section{LEVEL II SCOUR ANALYSIS FOR BRIDGE 12 (HUNTTH00010012) on TOWN HIGHWAY 1, crossing BRUSH BROOK, HUNTINGTON, VERMONT \\ By Ronda L. Burns and Emily C. Wild}

U.S. Geological Survey Open-File Report 97-226

Prepared in cooperation with

VERMONT AGENCY OF TRANSPORTATION and

FEDERAL HIGHWAY ADMINISTRATION 


\title{
U.S. DEPARTMENT OF THE INTERIOR BRUCE BABBITT, Secretary
}

\author{
U.S. GEOLOGICAL SURVEY \\ Gordon P. Eaton, Director
}

For additional information write to:

District Chief

U.S. Geological Survey 361 Commerce Way

Pembroke, NH 03275-3718
Copies of this report may be purchased from:

U.S. Geological Survey

Branch of Information Services

Open-File Reports Unit

Box 25286

Denver, CO 80225-0286 


\section{CONTENTS}

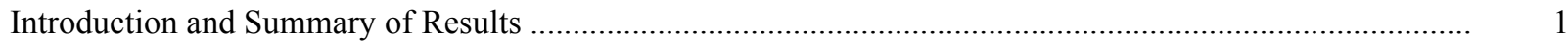

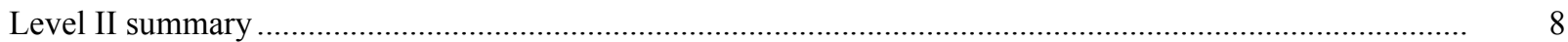

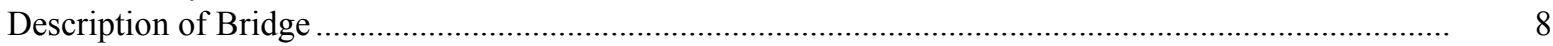

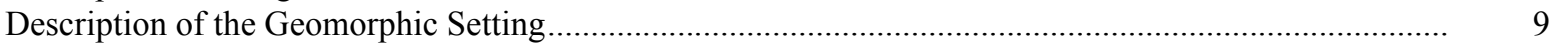

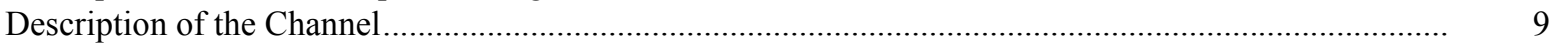

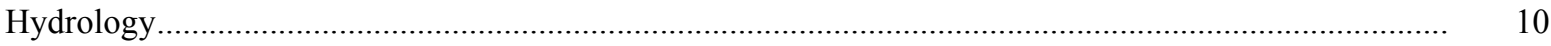

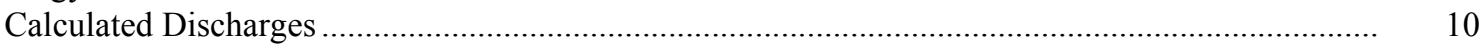

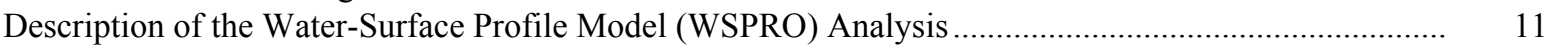

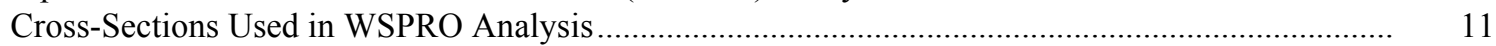

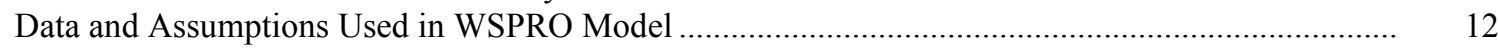

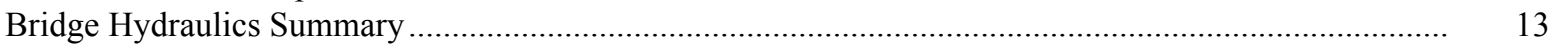

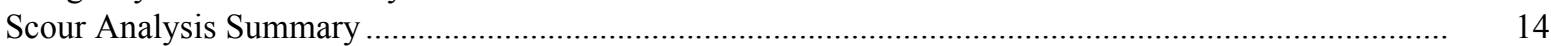

Special Conditions or Assumptions Made in Scour Analysis ...................................................... 14

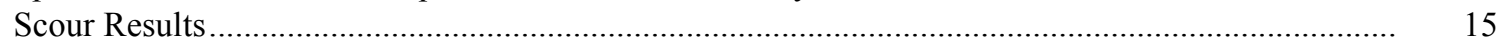

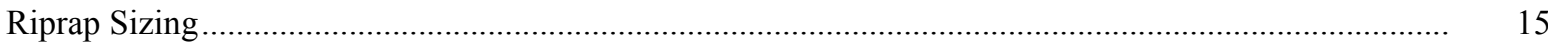

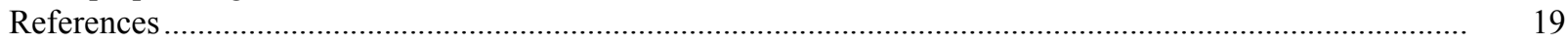

Appendixes:

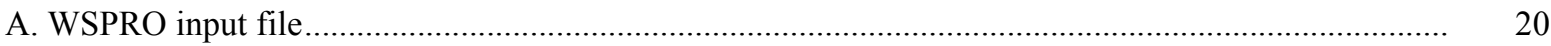

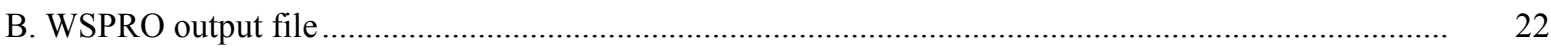

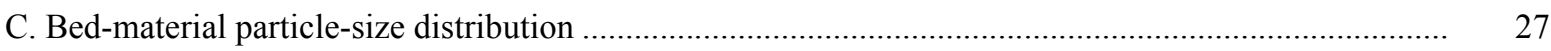

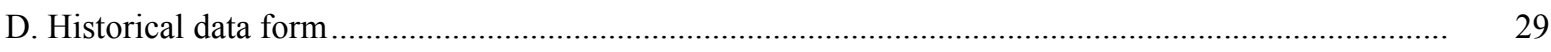

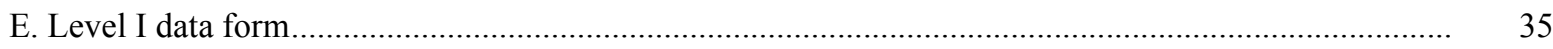

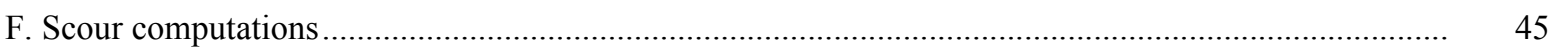

\section{FIGURES}

1. Map showing location of study area on USGS $1: 24,000$ scale map ........................................................ 3

2. Map showing location of study area on Vermont Agency of Transportation town

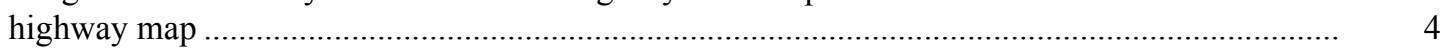

3. Structure HUNTTH00010012 viewed from upstream (June 25, 1996) .................................................

4. Downstream channel viewed from structure HUNTTH00010012 (June 25, 1996).............................. 5

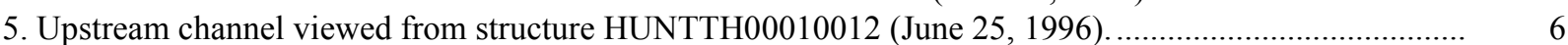

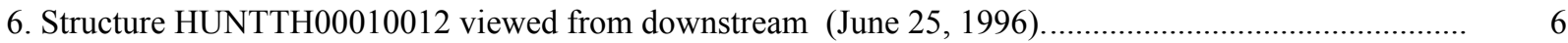

7. Right road approach viewed after flood of August 1976 ....................................................................

8. Water-surface profiles for the 100- and 500-year discharges at structure

HUNTTH00010012 on Town Highway 1, crossing Brush Brook,

Huntington, Vermont.

9. Scour elevations for the 100- and 500-year discharges at structure

HUNTTH00010012 on Town Highway 1, crossing Brush Brook,

Huntington, Vermont.

\section{TABLES}

1. Remaining footing/pile depth at abutments for the 100-year discharge at structure

HUNTTH00010012 on Town Highway 1, crossing Brush Brook,

Huntington, Vermont

2. Remaining footing/pile depth at abutments for the 500-year discharge at structure

HUNTTH00010012 on Town Highway 1, crossing Brush Brook,

Huntington, Vermont.... 


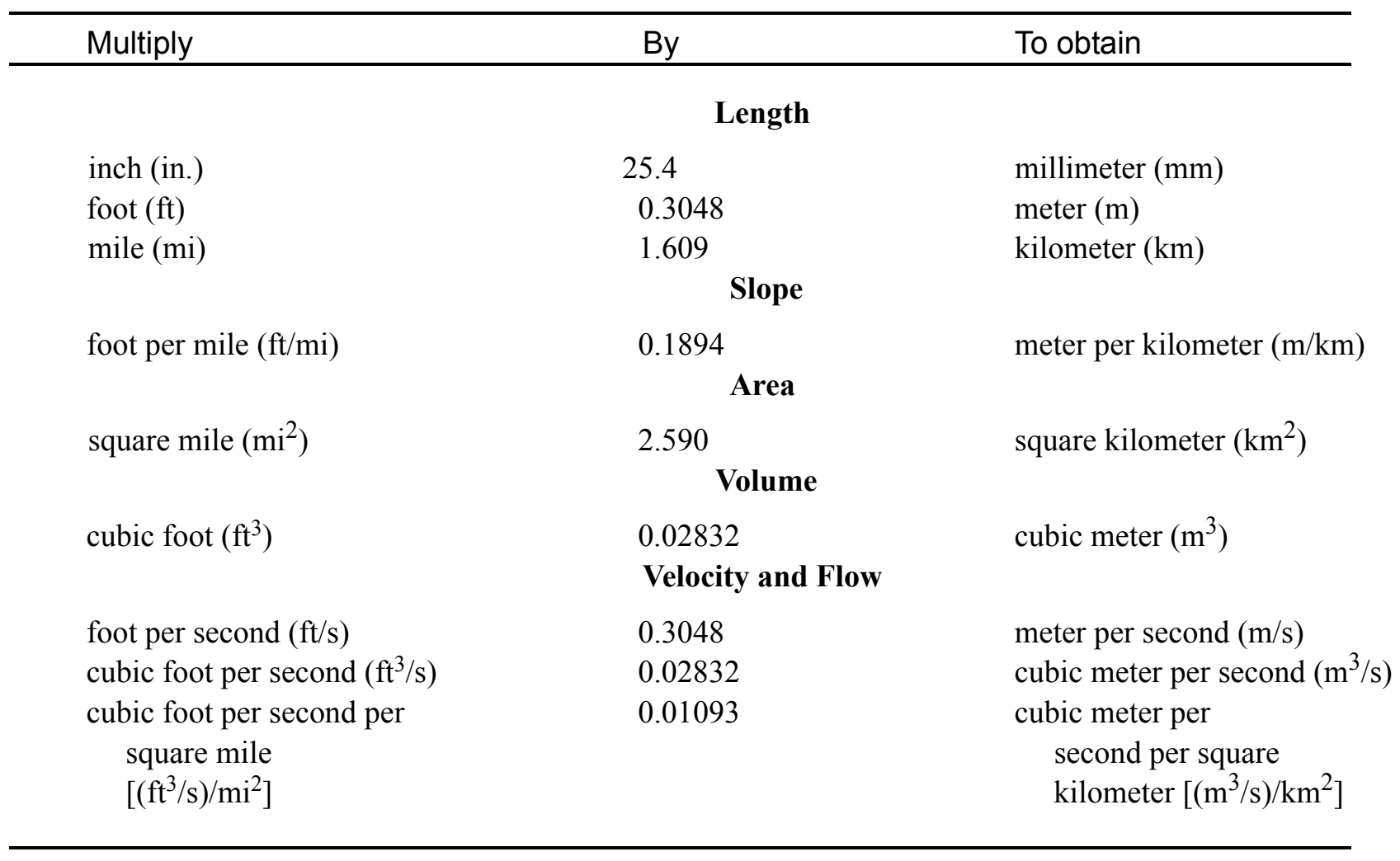

\section{OTHER ABBREVIATIONS}

$\begin{array}{lrlr}\mathrm{BF} & \text { bank full } & \text { LWW } & \text { left wingwall } \\ \mathrm{cfs} & \text { cubic feet per second } & \text { MC } & \text { main channel } \\ \mathrm{D}_{50} & \text { median diameter of bed material } & \text { RAB } & \text { right abutment } \\ \mathrm{DS} & \text { downstream } & \text { RABUT } & \text { face of right abutment } \\ \mathrm{elev} & \text { elevation } & \text { RB } & \text { right bank } \\ \mathrm{f} / \mathrm{p} & \text { flood plain } & \text { ROB } & \text { right overbank } \\ \mathrm{ft}^{2} & \text { square feet } & \text { RWW } & \text { right wingwall } \\ \mathrm{ft} / \mathrm{ft} & \text { feet per foot } & \text { TH } & \text { town highway } \\ \mathrm{JCT} & \text { junction } & \text { UB } & \text { under bridge } \\ \mathrm{LAB} & \text { left abutment } & \text { US } & \text { upstream } \\ \mathrm{LABUT} & \text { face of left abutment } & \text { USGS } & \text { United States Geological Survey } \\ \mathrm{LB} & \text { left bank } & \text { VTAOT Vermont Agency of Transportation } \\ \mathrm{LOB} & \text { left overbank } & \text { WSPRO } & \text { water-surface profile model }\end{array}$

In this report, the words "right" and "left" refer to directions that would be reported by an observer facing downstream. Sea level: In this report, "sea level" refers to the National Geodetic Vertical Datum of 1929-- a geodetic datum derived from a general adjustment of the first-order level nets of the United States and Canada, formerly called Sea Level Datum of 1929.

In the appendices, the above abbreviations may be combined. For example, USLB would represent upstream left bank. 


\title{
LEVEL II SCOUR ANALYSIS FOR BRIDGE 12 (HUNTTH00010012) ON TOWN HIGHWAY 1, CROSSING BRUSH BROOK, HUNTINGTON, VERMONT
}

\author{
By Ronda L. Burns and Emily C. Wild
}

\section{INTRODUCTION AND SUMMARY OF RESULTS}

This report provides the results of a detailed Level II analysis of scour potential at structure HUNTTH00010012 on Town Highway 1 crossing Brush Brook, Huntington, Vermont (figures 1-9). A Level II study is a basic engineering analysis of the site, including a quantitative analysis of stream stability and scour (U.S. Department of Transportation, 1993). Results of a Level I scour investigation also are included in Appendix E of this report. A Level I investigation provides a qualitative geomorphic characterization of the study site. Information on the bridge, gleaned from Vermont Agency of Transportation (VTAOT) files, was compiled prior to conducting Level I and Level II analyses and is found in Appendix D.

In August 1976, Hurricane Belle caused flooding at this site which resulted in road and bridge damage (figures 7-8). This was approximately a 25 -year flood event based on floodfrequency data contained in the Flood Insurance Study for the Town of Huntington (U.S. Department of Housing and Urban Development, 1978).

The site is in the Green Mountain section of the New England physiographic province in central Vermont. The $9.19-\mathrm{mi}^{2}$ drainage area is in a predominantly rural and forested basin. In the vicinity of the study site, the surface cover is pasture while the immediate banks have some woody vegetation.

In the study area, the Brush Brook has a sinuous channel with a slope of approximately 0.02 $\mathrm{ft} / \mathrm{ft}$, an average channel top width of $62 \mathrm{ft}$ and an average bank height of $5 \mathrm{ft}$. The channel bed material ranges from gravel to cobble with a median grain size $\left(D_{50}\right)$ of $100.0 \mathrm{~mm}$ $(0.328 \mathrm{ft})$. The geomorphic assessment at the time of the Level I and Level II site visit on June 25, 1996, indicated that the reach was stable.

The Town Highway 1 crossing of Brush Brook is a 64-ft-long, two-lane bridge consisting of one 62-foot steel-stringer span (Vermont Agency of Transportation, written communication, November 30,1995). The bridge is supported by vertical, concrete abutments with wingwalls. The channel is skewed approximately 10 degrees to the opening while the opening-skew-to-roadway is 6 degrees. 
Channel scour $2.2 \mathrm{ft}$ deeper than the mean thalweg depth was observed along the upstream right bank and along the base of the spill-through protection for the right abutment during the Level I assessment. Scour protection measured at the site was type-2 stone fill (less than 36 inches diameter) along the upstream left and right banks and in front of all four wingwalls. In front of the abutments, there was type- 3 stone fill (less than 48 inches diameter) forming a spill-through slope. Additional details describing conditions at the site are included in the Level II Summary and Appendices D and E.

Scour depths and recommended rock rip-rap sizes were computed using the general guidelines described in Hydraulic Engineering Circular 18 (Richardson and others, 1995). Total scour at a highway crossing is comprised of three components: 1) long-term streambed degradation; 2) contraction scour (due to accelerated flow caused by a reduction in flow area at a bridge) and; 3 ) local scour (caused by accelerated flow around piers and abutments). Total scour is the sum of the three components. Equations are available to compute depths for contraction and local scour and a summary of the results of these computations follows.

There was no computed contraction scour for any modelled flow. Abutment scour ranged from 1.4 to $2.8 \mathrm{ft}$. The worst-case abutment scour occurred at the 500-year discharge. Additional information on scour depths and depths to armoring are included in the section titled "Scour Results". Scoured-streambed elevations, based on the calculated scour depths, are presented in tables 1 and 2. A cross-section of the scour computed at the bridge is presented in figure 9. Scour depths were calculated assuming an infinite depth of erosive material and a homogeneous particle-size distribution.

It is generally accepted that the Froehlich equation (abutment scour) gives "excessively conservative estimates of scour depths" (Richardson and others, 1995, p. 47). Usually, computed scour depths are evaluated in combination with other information including (but not limited to) historical performance during flood events, the geomorphic stability assessment, existing scour protection measures, and the results of the hydraulic analyses. Therefore, scour depths adopted by VTAOT may differ from the computed values documented herein. 


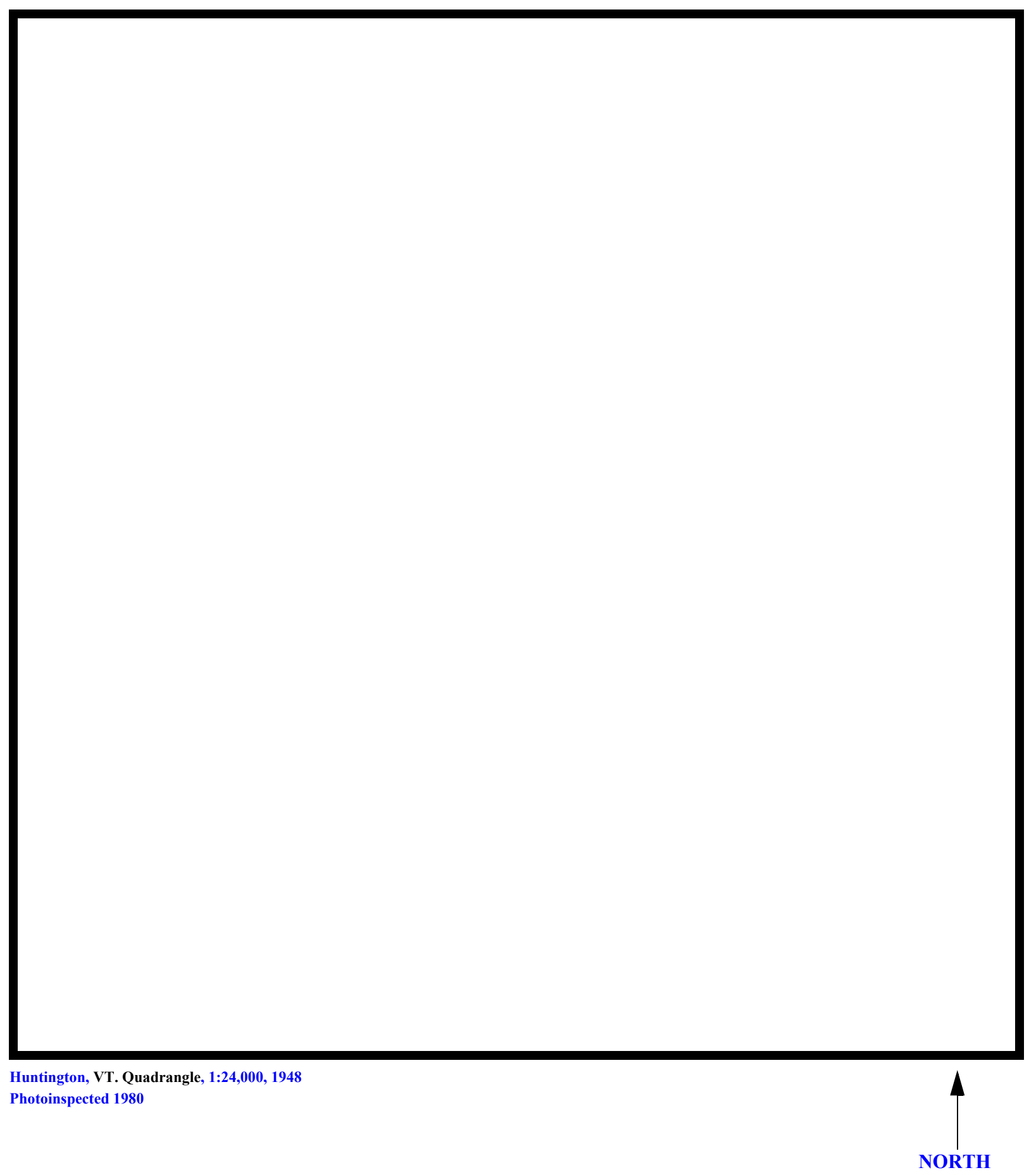

Figure 1. Location of study area on USGS 1:24,000 scale map. 
Figure 2. Location of study area on Vermont Agency of Transportation town highway map. 

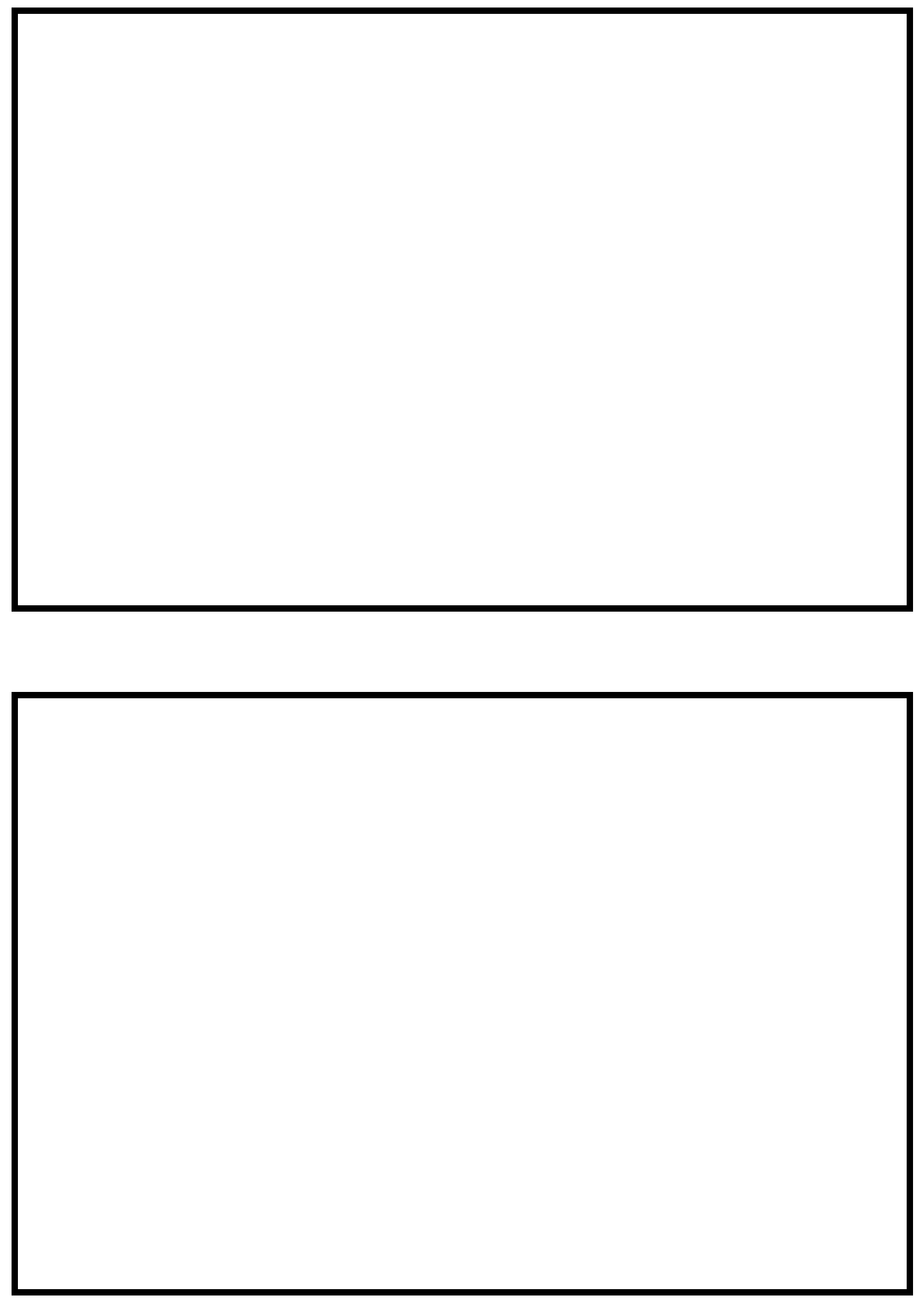

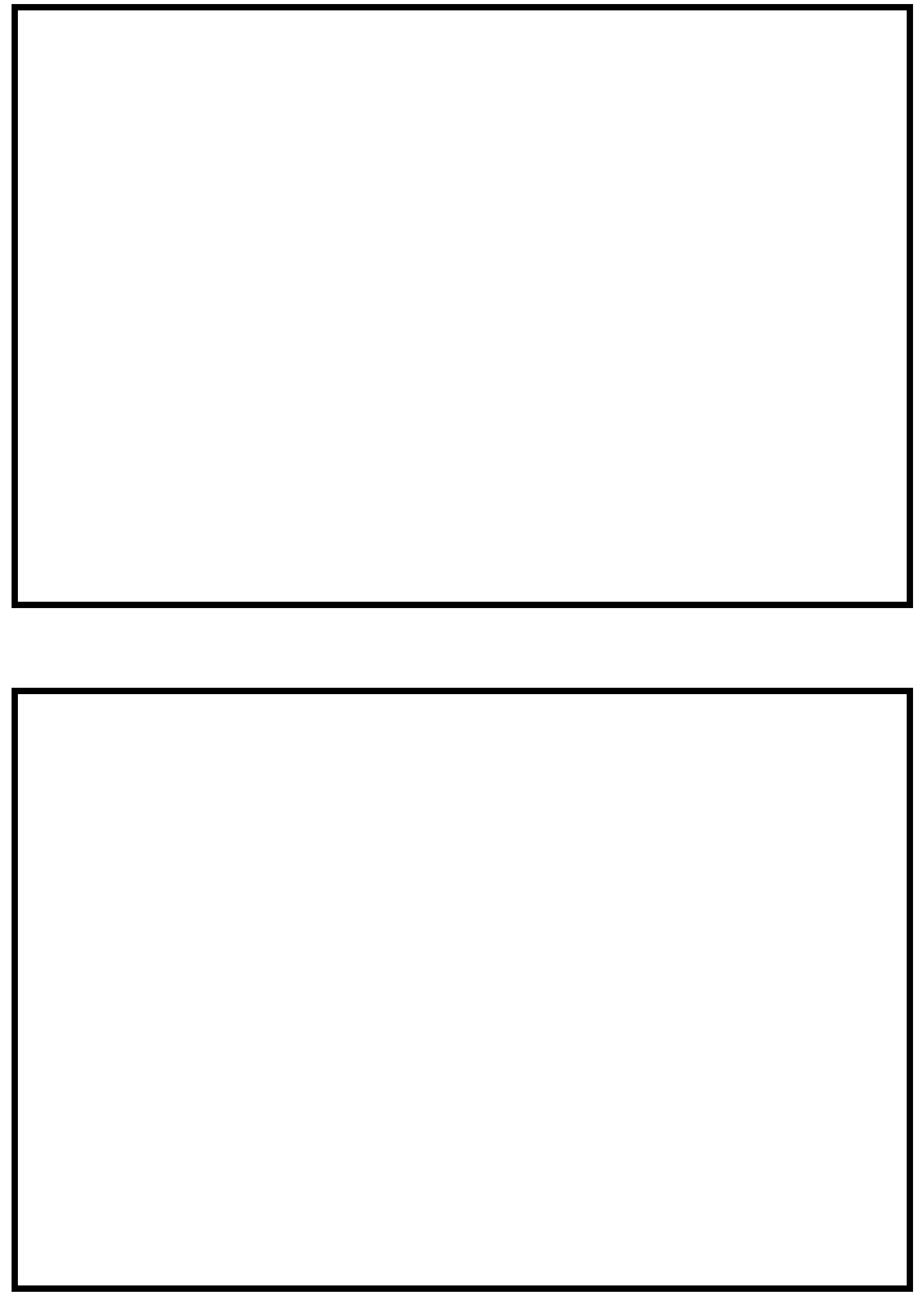


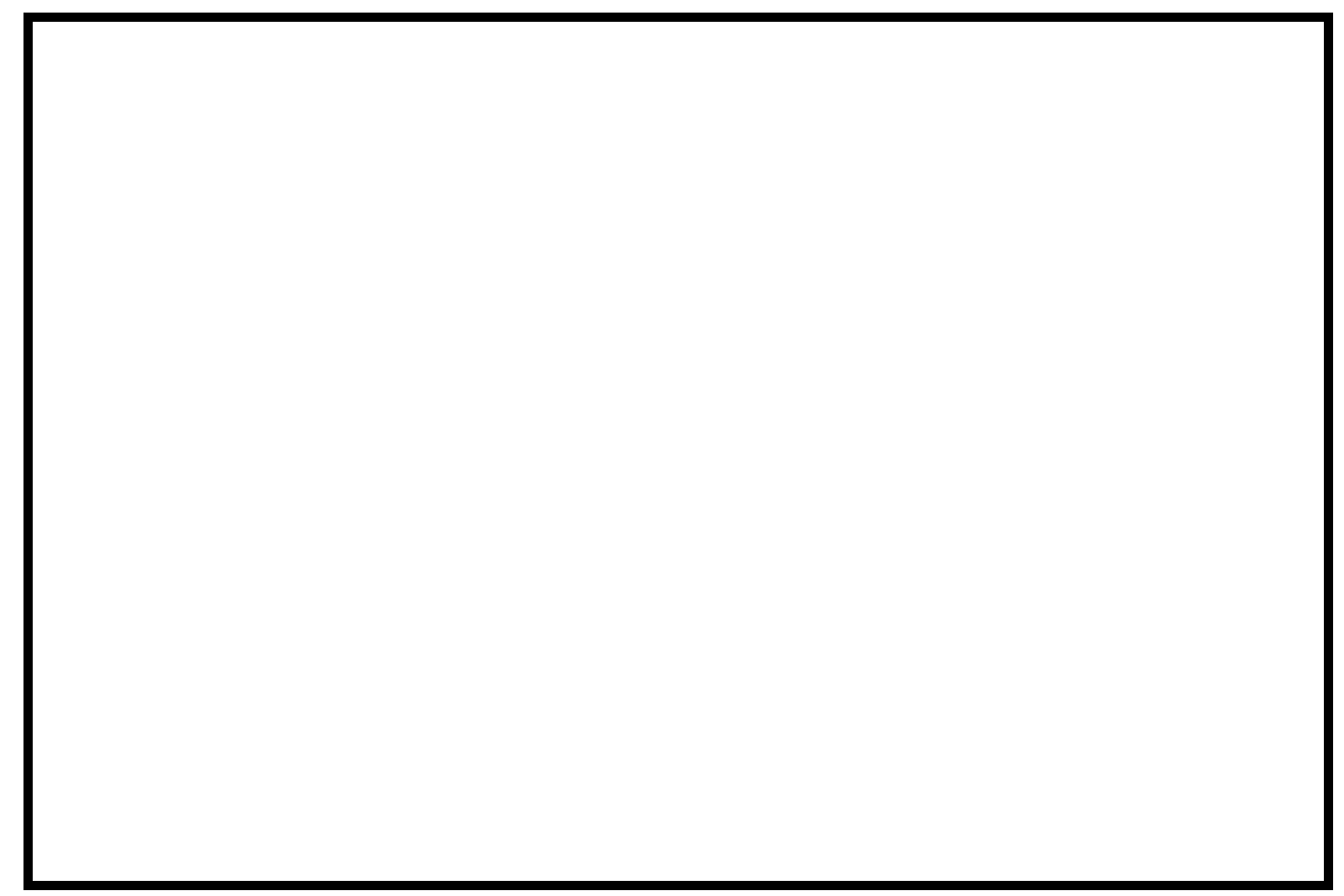

Figure 7. Right road approach viewed after the August 1976 flood which destroyed the bridge (U.S. Department of Housing and Urban Development, 1978). 


\section{LEVEL II SUMMARY}

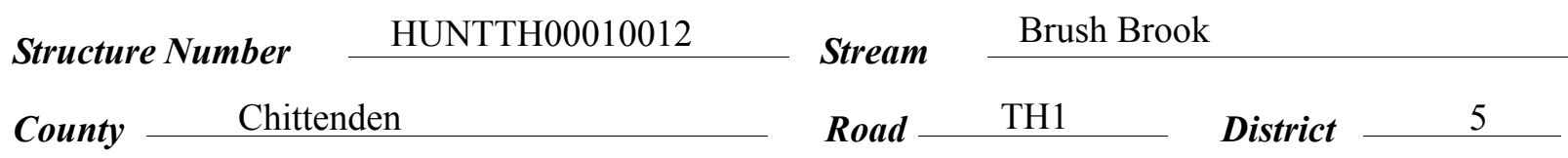

\section{Description of Bridge}

Bridge length $\frac{64}{2} f t \quad$ Bridge width $\stackrel{31.4}{f} \quad$ Max span length $\frac{62}{f t}$ Alignment of bridge to road (on curve or straight) Spill-through Abutment type

Stone fill on abutment?

$$
\text { Yes }
$$

\section{Embankment type} Sloping Straight Macmintinu af nta... n fill Type-3, along the entire baselengths of both abutments forming spillthrough slopes at the faces of the abutments.

Abutments and wingwalls are concrete. There is a one to two foot deep scour hole in front of the right abutment protection that is the extension of a channel scour hole from upstream.

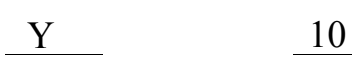

Is bridge skewed to flood flow according to N_ survey? Angle

Debris accumulation on bridge at time of Level I or Level II site visit:

\begin{tabular}{|c|c|c|c|}
\hline & $\begin{array}{c}\text { Date of insnortion } \\
06 / 25 / 96 \\
\end{array}$ & $\begin{array}{l}\text { Percent of ahmunal } \\
\text { blocked inortzontatly }\end{array}$ & $\begin{array}{l}\text { Percent of } 0 \\
\text { blocked verticatty }\end{array}$ \\
\hline Level I & $06 / 25 / 96$ & 0 & 0 \\
\hline Level II & \multicolumn{3}{|c|}{ Moderate. There is debris accumulated on the side bars between the } \\
\hline
\end{tabular}

None. (June 25, 1996)

Dosriho anv, foaturos noar ar at tho hridoo that mav affort flow, (includo ahsorvation dato) 


\section{Description of the Geomorphic Setting}

General topography The channel is located within the wide, flat to slightly irregular flood plain of the Huntington River and has steep valley walls on both sides upstream.

Geomorphic conditions at bridge site: downstream (DS), upstream (US)

Date of inspection $\quad 06 / 25 / 96$

DS left: $\quad$ Wide flood plain.

DS right: Wide flood plain.

US left: $\quad$ Wide flood plain.

US right: Wide flood plain.

\section{Description of the Channel}

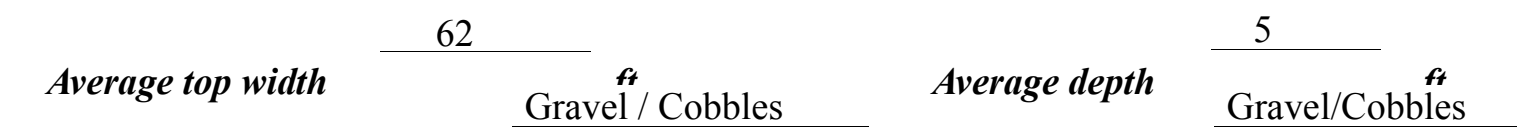

Predominant bed material

Bank material

Sinuous but stable

with semi-allúvial channel boundaries and a wide flood plain.

Vegetative col ${ }^{1}$ Short grass on the overbank with brush with a few trees on the immediate bank.

DS left: $\quad$ Short grass on the overbank with brush with a few trees on the immediate bank.

DS right: $\quad$ Short grass on the overbank with brush with a few trees on the immediate bank.

US left: $\quad$ Short grass on the overbank with brush with a few trees on the immediate bank.

US right: $\quad \underline{\mathrm{Y}}$

Do banks appear stable? -

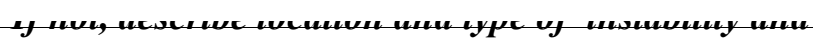

date of observatton.

None. (June 25, 1996)

Describe any obstructions in channel and date of observation. 


\title{
Hydrology
}

Drainage area $\frac{9.19}{m_{i}{ }^{2}}$

Percentage of drainage area in physiographic provinces: (approximate)

Physiographic province/section

New England/Green Mountain
Percent of drainage area 100

\begin{abstract}
Is drainage area considered rural or urban? Rural Describe any significant urbanization: None.
\end{abstract}

Is there a

Is there a USGS gage on the stream of interest? USGS gage description

USGS gage number

Gage drainage area $\mathrm{mi}^{2}$

Is there a lake/p

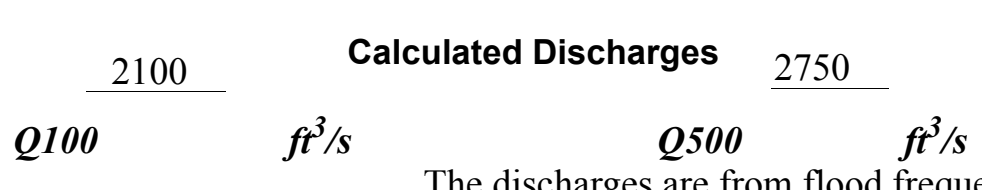

The discharges are from flood frequency estimates

available from the VTAOT database (written communication, VTAOT, May 1995) graphically extrapolated to the 500 -year event. The values used were within a range defined by flood frequency curves developed from several empirical methods (Benson, 1962; Johnson and Tasker, 1974; FHWA, 1983; Potter, 1957a\&b; Talbot, 1887). 


\section{Description of the Water-Surface Profile Model (WSPRO) Analysis}

Datum for WSPRO analysis (USGS survey, sea level, VTAOT plans)

USGS survey

Datum tie between USGS survey and VTAOT plans

Add $0.6 \mathrm{ft}$. to USGS arbitrary

survey datum to obtain VTAOT plans' datum.

Description of reference marks used to determine USGS datum. $\quad$ RM1 is a brass tablet on

top of the upstream end of the left abutment (elev. $500.89 \mathrm{ft}$., arbitrary survey datum). RM2 is a chiseled

$\mathrm{X}$ on top of the downstream end of the right abutment (elev. $500.39 \mathrm{ft}$., arbitrary survey datum). RM3 is a

spike $6 \mathrm{ft}$. above the ground in a telephone pole $50 \mathrm{ft}$. from the left bank and $20 \mathrm{ft}$. downstream from the

road (elev. 504.39 ft., arbitrary survey datum).

\section{Cross-Sections Used in WSPRO Analysis}

\begin{tabular}{cccl}
\hline${ }^{1}$ Cross-section & $\begin{array}{c}\text { Section } \\
\text { Reference } \\
\text { Distance } \\
\text { (SRD) } \text { in feet }\end{array}$ & $\begin{array}{c}{ }^{2} \text { Cross-section } \\
\text { development }\end{array}$ & \multicolumn{1}{c}{ Comments } \\
\hline EXITX & -52 & 1 & $\begin{array}{l}\text { Exit section } \\
\text { Downstream Full-valley } \\
\text { section (Templated from } \\
\text { EXITX) }\end{array}$ \\
FULLV & 0 & 2 & $\begin{array}{l}\text { Bridge section } \\
\text { Road Grade section }\end{array}$ \\
RDWHY & 0 & 1 & $\begin{array}{l}\text { Modelled Approach sec- } \\
\text { tion (Templated from } \\
\text { APTEM) }\end{array}$ \\
APTEM & 17 & 1 & $\begin{array}{l}\text { Approach section as sur- } \\
\text { veyed (Used as a tem- } \\
\text { plate) }\end{array}$ \\
\hline
\end{tabular}

${ }^{1}$ For location of cross-sections see plan-view sketch included with Level I field form, Appendix E.

For more detail on how cross-sections were developed see WSPRO input file. 


\section{Data and Assumptions Used in WSPRO Model}

Hydraulic analyses of the reach were done by use of the Federal Highway Administration's WSPRO step-backwater computer program (Shearman and others, 1986, and Shearman, 1990). The analyses reported herein reflect conditions existing at the site at the time of the study. Furthermore, in the development of the model it was necessary to assume no accumulation of debris or ice at the site. Results of the hydraulic model are presented in the Bridge Hydraulic Summary, Appendix B, and figure 8.

Channel roughness factors (Manning's " $n$ ") used in the hydraulic model were estimated using field inspections at each cross section following the general guidelines described by Arcement and Schneider (1989). Final adjustments to the values were made during the modelling of the reach. Channel " $n$ " values for the reach ranged from 0.040 to 0.055 , and overbank " $\mathrm{n}$ " values ranged from 0.035 to 0.040 .

Normal depth at the exit section (EXITX) was assumed as the starting water surface. This depth was computed by use of the slope-conveyance method outlined in the user's manual for WSPRO (Shearman, 1990). The slope used was $0.0162 \mathrm{ft} / \mathrm{ft}$ which was calculated from surveyed thalweg points downstream. Brush Brook flows into the Huntington River 0.1 mile downstream. There is a possibility of backwater from the Huntington River if peaks at the confluence occur simultaneously. Assuming normal depth as the starting water surface will provide the worst-case scenario.

The surveyed approach section (APTEM) was moved along the approach channel slope $(0.0055 \mathrm{ft} / \mathrm{ft})$ to establish the modelled approach section (APPRO), one bridge length upstream of the upstream face as recommended by Shearman and others (1986). This approach also provides a consistent method for determining scour variables.

The 100-year flow in this case is also the incipient road-overflow discharge. 


\section{Bridge Hydraulics Summary}

$\begin{array}{llll}\text { Average bridge embankment elevation } & 500.6 & f t \\ \text { Average low steel elevation } & 496.4 & f t\end{array}$

100-year discharge $\quad 2,100 \quad \mathrm{ft}^{3} / \mathrm{s}$

Water-surface elevation in bridge opening $\quad 495.3 \quad f t$

Road overtopping? __ N Discharge over road _ $\quad 0, \ldots$

\begin{tabular}{lll} 
Area of flow in bridge opening & $266 \quad \mathrm{ft}^{2}$ \\
\cline { 2 - 3 } Average velocity in bridge opening & 7.9 & $\mathrm{ft} / \mathrm{s}$
\end{tabular}

Maximum WSPRO tube velocity at bridge $\quad 9.5 \mathrm{ft} / \mathrm{s}$

Water-surface elevation at Approach section with bridge 496.5

Water-surface elevation at Approach section without bridge $\quad 496.3$

Amount of backwater caused by bridge

0.2 it

500-year discharge $\quad 2,750 \quad \mathrm{ft}^{3} / \mathrm{s}$

Water-surface elevation in bridge opening

$495.6 f t$

Road overtopping? ___ Y Discharge over road _ $\quad 765, \% / s$

Area of flow in bridge opening $\quad 287 \quad \mathrm{ft}^{2}$

Average velocity in bridge opening $6.92 \mathrm{ft} / \mathrm{s}$

Maximum WSPRO tube velocity at bridge 8.1 , 's

Water-surface elevation at Approach section with bridge 496.9

Water-surface elevation at Approach section without bridge $\quad 496.7$

Amount of backwater caused by bridge 0.2 .

Incipient overtopping discharge ___ _ $\mathrm{ft}^{3} / \mathrm{s}$

Water-surface elevation in bridge opening $\quad-\quad t$

Area of flow in bridge opening

$\begin{array}{llll}- & f t^{2} & \\ & - & f t / s & f t / s\end{array}$

Maximum WSPRO tube velocity at bridge $f t / s$

Water-surface elevation at Approach section with bridge

Water-surface elevation at Approach section without bridge Amount of backwater caused by bridge $-\quad t$ 


\section{Scour Analysis Summary}

\section{Special Conditions or Assumptions Made in Scour Analysis}

Scour depths were computed using the general guidelines described in Hydraulic Engineering Circular 18 (Richardson and others, 1995). Scour depths were calculated assuming an infinite depth of erosive material and a homogeneous particle-size distribution. The results of the scour analysis are presented in tables 1 and 2 and a graph of the scour depths is presented in figure 9 .

Contraction scour was computed by use of the clear-water contraction scour equation (Richardson and others, 1995, p. 32, equation 20). There was no computed contraction scour for any modelled flows. Streambed armoring computations indicate that contraction scour will not be limited by armoring.

Scour at the abutments for the 100- and 500-year discharges was computed by use of the HIRE equation (Richardson and others, 1995, p. 49, equation 29) because the HIRE equation is recommended when the length to depth ratio of the embankment blocking flow exceeds 25 . The variables used by the HIRE abutment-scour equation include the Froude number of the flow approaching the embankments, the length of the embankment blocking flow, and the depth of flow approaching the embankment less any roadway overtopping. The 500-year flow resulted in the worst case total scour. 


\section{Scour Results}

Incipient

Contraction scour:

Main channel

$$
\begin{aligned}
& \text { Live-bed scour } \\
& \text { Clear-water scour } \\
& \text { Depth to armoring }
\end{aligned}
$$

Left overbank

Right overbank

Local scour:

Abutment scour

Left abutment

1.7

2.8

1.4

$2.8-$

\section{Right abutment}

Pier scour

Pier 1

Pier 2

Pier 3

Abutments:

Left abutment

Right abutment

Piers:

Pier 1

Pier 2

100-yr discharge 500-yr discharge

(Scour depths in feet)

overtopping discharge
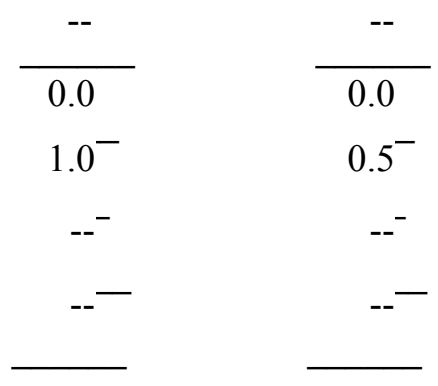

$0.5^{-}$

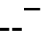

$--$

$--^{-}$

--

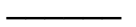

\section{Riprap Sizing}

Incipient overtopping 100-yr discharge 500-yrdischarge discharge

1.3 ( $D_{50}$ in feet)

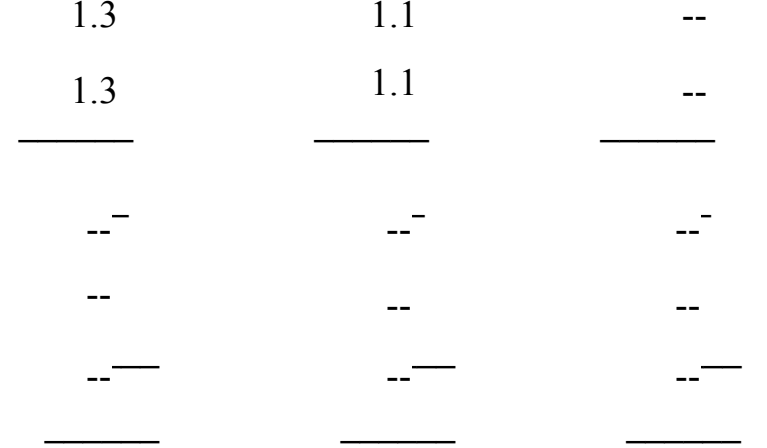




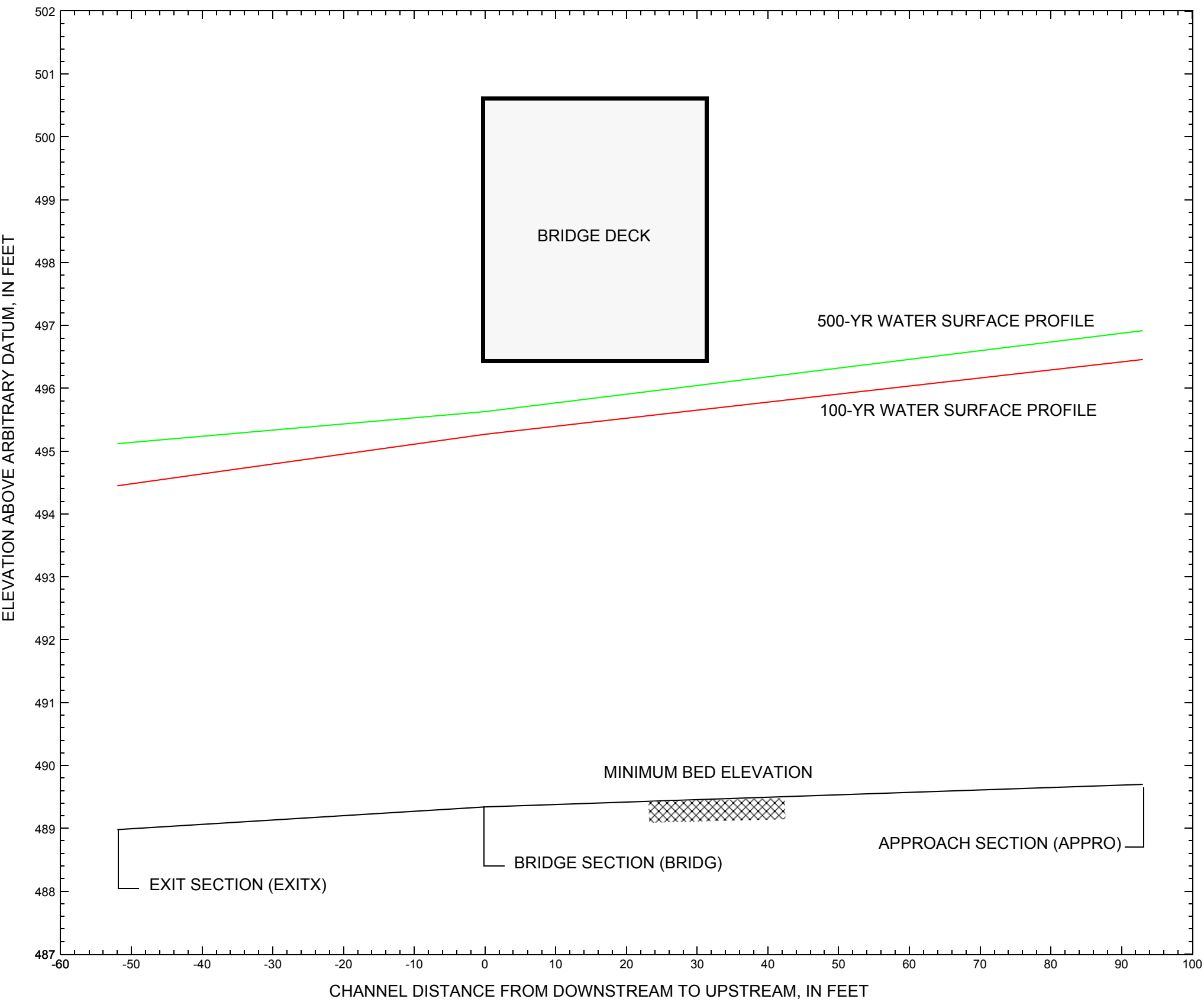

Figure 8. Water-surface profiles for the 100- and 500-yr discharges at structure HUNTTH00010012 on Town Highway 01, crossing Brush Brook, Huntington, Vermont. 


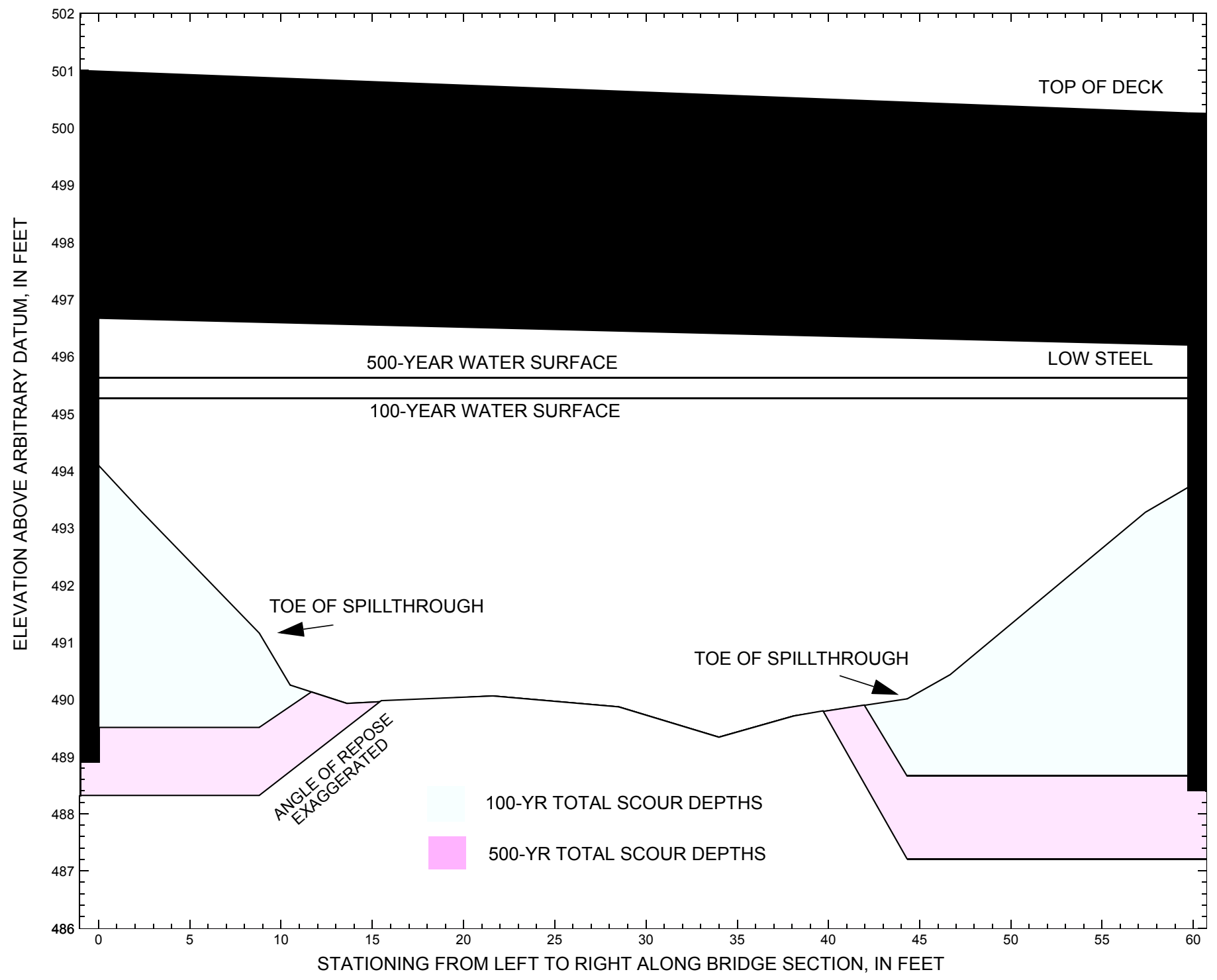

Figure 9. Scour elevations for the 100-yr and 500-yr discharges at structure HUNTTH00010012 on Town Highway 01, crossing Brush Brook, Huntington, Vermont. 
Table 1. Remaining footing/pile depth at abutments for the 100-year discharge at structure HUNTTH00010012 on Town Highway 01, crossing Brush Brook, Huntington, Vermont.

[VTAOT, Vermont Agency of Transportation; --, no data]

\begin{tabular}{|c|c|c|c|c|c|c|c|c|c|c|c|}
\hline Description & Station $^{1}$ & $\begin{array}{l}\text { VTAOT } \\
\text { minimum } \\
\text { bridge seat } \\
\text { elevation } \\
\text { (feet) }\end{array}$ & $\begin{array}{l}\text { Surveyed } \\
\text { minimum } \\
\text { low-chord } \\
\text { elevation } \\
\text { (feet) }\end{array}$ & $\begin{array}{l}\text { Bottom of } \\
\text { footing } \\
\text { elevation } \\
\text { (feet) }\end{array}$ & $\begin{array}{c}\text { Channel } \\
\text { elevation at } \\
\text { abutment/ } \\
\text { pier }^{2} \\
\text { (feet) }\end{array}$ & $\begin{array}{l}\text { Contraction } \\
\text { scour depth } \\
\text { (feet) }\end{array}$ & $\begin{array}{c}\text { Abutment } \\
\text { scour } \\
\text { depth } \\
\text { (feet) }\end{array}$ & $\begin{array}{l}\text { Pier } \\
\text { scour } \\
\text { depth } \\
\text { (feet) }\end{array}$ & $\begin{array}{l}\text { Depth of } \\
\text { total scour } \\
\text { (feet) }\end{array}$ & $\begin{array}{c}\text { Elevation of } \\
\text { scour }^{2} \\
\text { (feet) }\end{array}$ & $\begin{array}{c}\text { Remaining } \\
\text { footing/pile } \\
\text { depth } \\
\text { (feet) }\end{array}$ \\
\hline \multicolumn{12}{|c|}{100 -yr. discharge is 2100 cubic-feet per second } \\
\hline Left abutment & 0.0 & 497.2 & 496.7 & 488.9 & 494.1 & 0.0 & -- & -- & -- & -- & 0.6 \\
\hline LABUT toe & 8.8 & -- & -- & -- & 491.2 & 0.0 & 1.7 & -- & 1.7 & 489.5 & -- \\
\hline RABUT toe & 44.3 & -- & -- & -- & 490.0 & 0.0 & 1.4 & -- & 1.4 & 488.6 & -- \\
\hline Right abutment & 59.7 & 496.6 & 496.2 & 488.4 & 493.7 & 0.0 & -- & -- & -- & -- & 0.2 \\
\hline
\end{tabular}

1.Measured along the face of the most constricting side of the bridge.

2.Arbitrary datum for this study.

Table 2. Remaining footing/pile depth at abutments for the 500-year discharge at structure HUNTTH00010012 on Town Highway 01, crossing Brush Brook, Huntington, Vermont.

[VTAOT, Vermont Agency of Transportation; --, no data]

\begin{tabular}{|c|c|c|c|c|c|c|c|c|c|c|c|}
\hline Description & Station $^{1}$ & $\begin{array}{l}\text { VTAOT } \\
\text { minimum } \\
\text { bridge seat } \\
\text { elevation } \\
\text { (feet) }\end{array}$ & $\begin{array}{l}\text { Surveyed } \\
\text { minimum } \\
\text { low-chord } \\
\text { elevation } \\
\quad \text { (feet) }\end{array}$ & $\begin{array}{c}\text { Bottom of } \\
\text { footing } \\
\text { elevation } \\
\text { (feet) }\end{array}$ & $\begin{array}{c}\text { Channel } \\
\text { elevation at } \\
\text { abutment/ } \\
\text { pier }^{2} \\
\text { (feet) }\end{array}$ & $\begin{array}{l}\text { Contraction } \\
\text { scour depth } \\
\text { (feet) }\end{array}$ & $\begin{array}{l}\text { Abutment } \\
\text { scour } \\
\text { depth } \\
\text { (feet) }\end{array}$ & $\begin{array}{l}\text { Pier } \\
\text { scour } \\
\text { depth } \\
\text { (feet) }\end{array}$ & $\begin{array}{l}\text { Depth of } \\
\text { total scour } \\
\text { (feet) }\end{array}$ & $\begin{array}{c}\text { Elevation of } \\
\text { scour }^{2} \\
\text { (feet) }\end{array}$ & $\begin{array}{c}\text { Remaining } \\
\text { footing/pile } \\
\text { depth } \\
\text { (feet) }\end{array}$ \\
\hline \multicolumn{12}{|c|}{500 -yr. discharge is 2750 cubic-feet per second } \\
\hline Left abutment & 0.0 & 497.2 & 496.7 & 488.9 & 494.1 & 0.0 & -- & -- & -- & -- & -0.5 \\
\hline LABUT toe & 8.8 & -- & -- & -- & 491.2 & 0.0 & 2.8 & -- & 2.8 & 488.4 & -- \\
\hline RABUT toe & 44.3 & -- & -- & -- & 490.0 & 0.0 & 2.8 & -- & 2.8 & 487.2 & -- \\
\hline Right abutment & 59.7 & 496.6 & 496.2 & 488.4 & 493.7 & 0.0 & -- & -- & -- & -- & -1.2 \\
\hline
\end{tabular}

1.Measured along the face of the most constricting side of the bridge.

2.Arbitrary datum for this study. 


\section{SELECTED REFERENCES}

Arcement, G.J., Jr., and Schneider, V.R., 1989, Guide for selecting Manning's roughness coefficients for natural channels and flood plains: U.S. Geological Survey Water-Supply Paper 2339, 38 p.

Barnes, H.H., Jr., 1967, Roughness characteristics of natural channels: U.S. Geological Survey Water-Supply Paper 1849,213 p.

Benson, M. A., 1962, Factors Influencing the Occurrence of Floods in a Humid Region of Diverse Terrain: U.S. Geological Survey WaterSupply Paper 1580-B, 64 p.

Brown, S.A. and Clyde, E.S., 1989, Design of riprap revetment: Federal Highway Administration Hydraulic Engineering Circular No. 11, Publication FHWA-IP-89-016, 156 p.

Federal Highway Administration, 1983, Runoff estimates for small watersheds and development of sound design: Federal Highway Administration Report FHWA-RD-77-158

Froehlich, D.C., 1989, Local scour at bridge abutments in Ports, M.A., ed., Hydraulic Engineering--Proceedings of the 1989 National Conference on Hydraulic Engineering: New York, American Society of Civil Engineers, p. 13-18.

Hayes, D.C.,1993, Site selection and collection of bridge-scour data in Delaware, Maryland, and Virginia: U.S. Geological Survey WaterResources Investigation Report 93-4017, 23 p.

Interagency Advisory Committee on Water Data, 1982, Guidelines for determining flood flow frequency: U.S. Geological Survey, Bulletin 17B of the Hydrology Subcommittee, 190 p.

Johnson, C.G. and Tasker, G.D.,1974, Progress report on flood magnitude and frequency of Vermont streams: U.S. Geological Survey OpenFile Report 74-130, 37 p.

Lagasse, P.F., Schall, J.D., Johnson, F., Richardson, E.V., Chang, F., 1995, Stream Stability at Highway Structures: Federal Highway Administration Hydraulic Engineering Circular No. 20, Publication FHWA-IP-90-014, 144 p.

Laursen, E.M., 1960, Scour at bridge crossings: Journal of the Hydraulics Division, American Society of Civil Engineers, v. 86, no. HY2, p. 39-53.

Potter, W. D., 1957a, Peak rates of runoff in the Adirondack, White Mountains, and Maine woods area, Bureau of Public Roads

Potter, W. D., 1957b, Peak rates of runoff in the New England Hill and Lowland area, Bureau of Public Roads

Richardson, E.V. and Davis, S.R., 1995, Evaluating scour at bridges: Federal Highway Administration Hydraulic Engineering Circular No. 18, Publication FHWA-IP-90-017, 204 p.

Richardson, E.V., Simons, D.B., and Julien, P.Y., 1990, Highways in the river environment: Federal Highway Administration Publication FHWA-HI-90-016.

Ritter, D.F., 1984, Process Geomorphology: W.C. Brown Co., Debuque, Iowa, 603 p.

Shearman, J.O., 1990, User's manual for WSPRO--a computer model for water surface profile computations: Federal Highway Administration Publication FHWA-IP-89-027, 187 p.

Shearman, J.O., Kirby, W.H., Schneider, V.R., and Flippo, H.N., 1986, Bridge waterways analysis model; research report: Federal Highway Administration Publication FHWA-RD-86-108, 112 p.

Talbot, A.N., 1887, The determination of water-way for bridges and culverts.

U. S. Department of Housing and Urban Development, 1978, Flood Insurance Study, Town of Huntington, Chittenden County, Vermont: Washington, D.C., January 1978.

U.S. Department of Transportation, 1993, Stream stability and scour at highway bridges, Participant Workbook: Federal Highway Administration Publication FHWA HI-91-011.

U.S. Geological Survey, 1948, Huntington, Vermont 7.5 Minute Series quadrangle map: U.S. Geological Survey Topographic Maps, Photoinspected 1980, Scale 1:24,000. 


\section{APPENDIX A: \\ WSPRO INPUT FILE}




\section{APPENDIX B: \\ WSPRO OUTPUT FILE}


WSPRO OUTPUT FILE

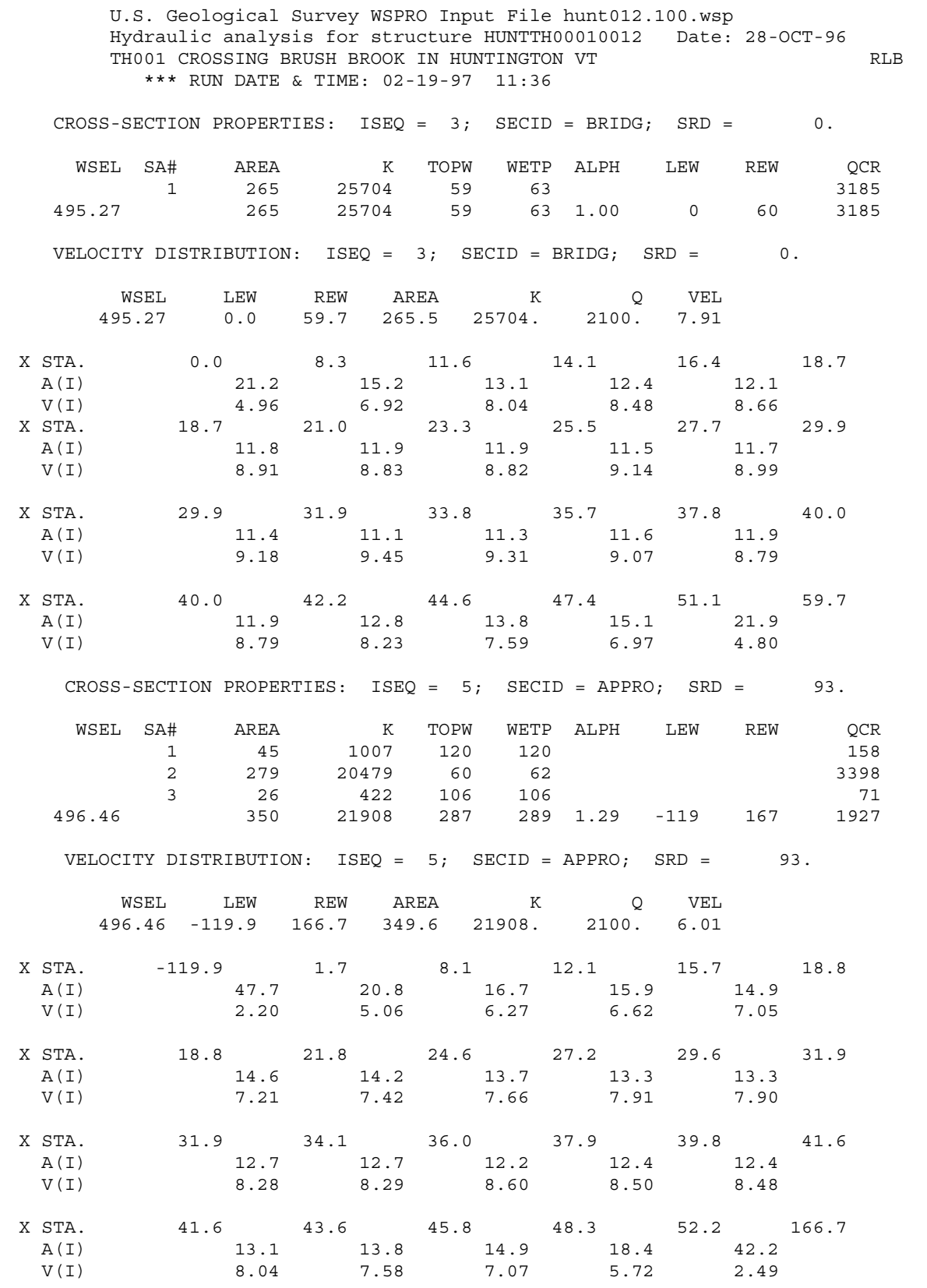


WSPRO OUTPUT FILE (continued)

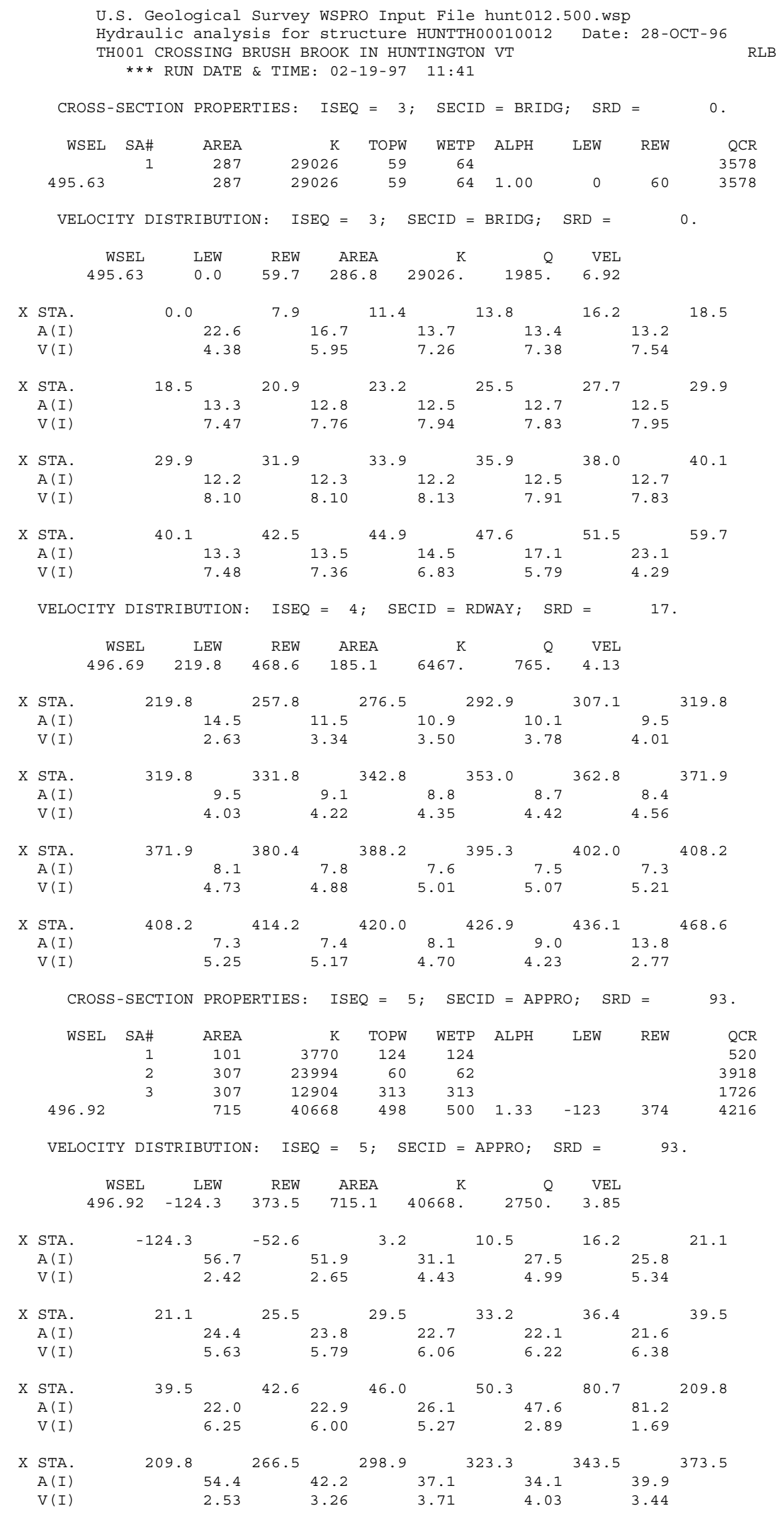


WSPRO OUTPUT FILE (continued)

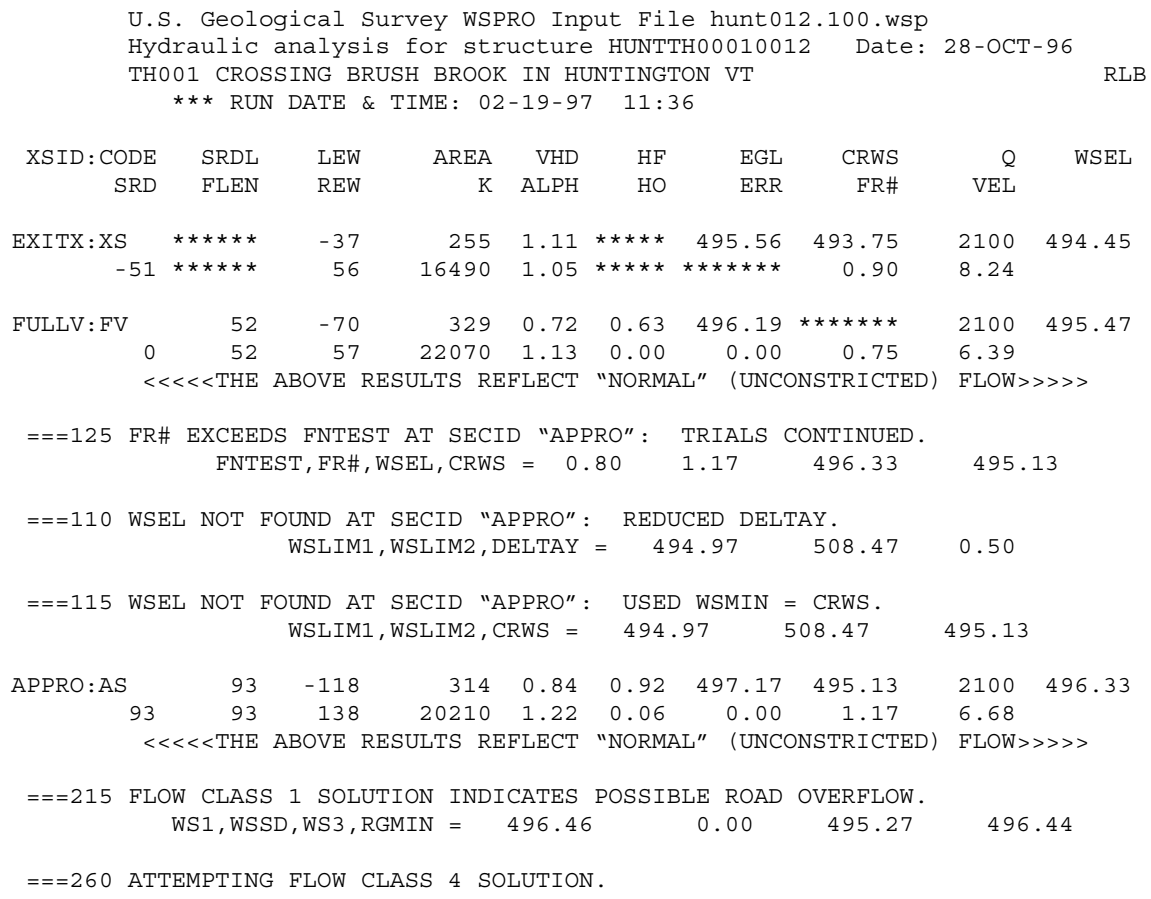


WSPRO OUTPUT FILE (continued)

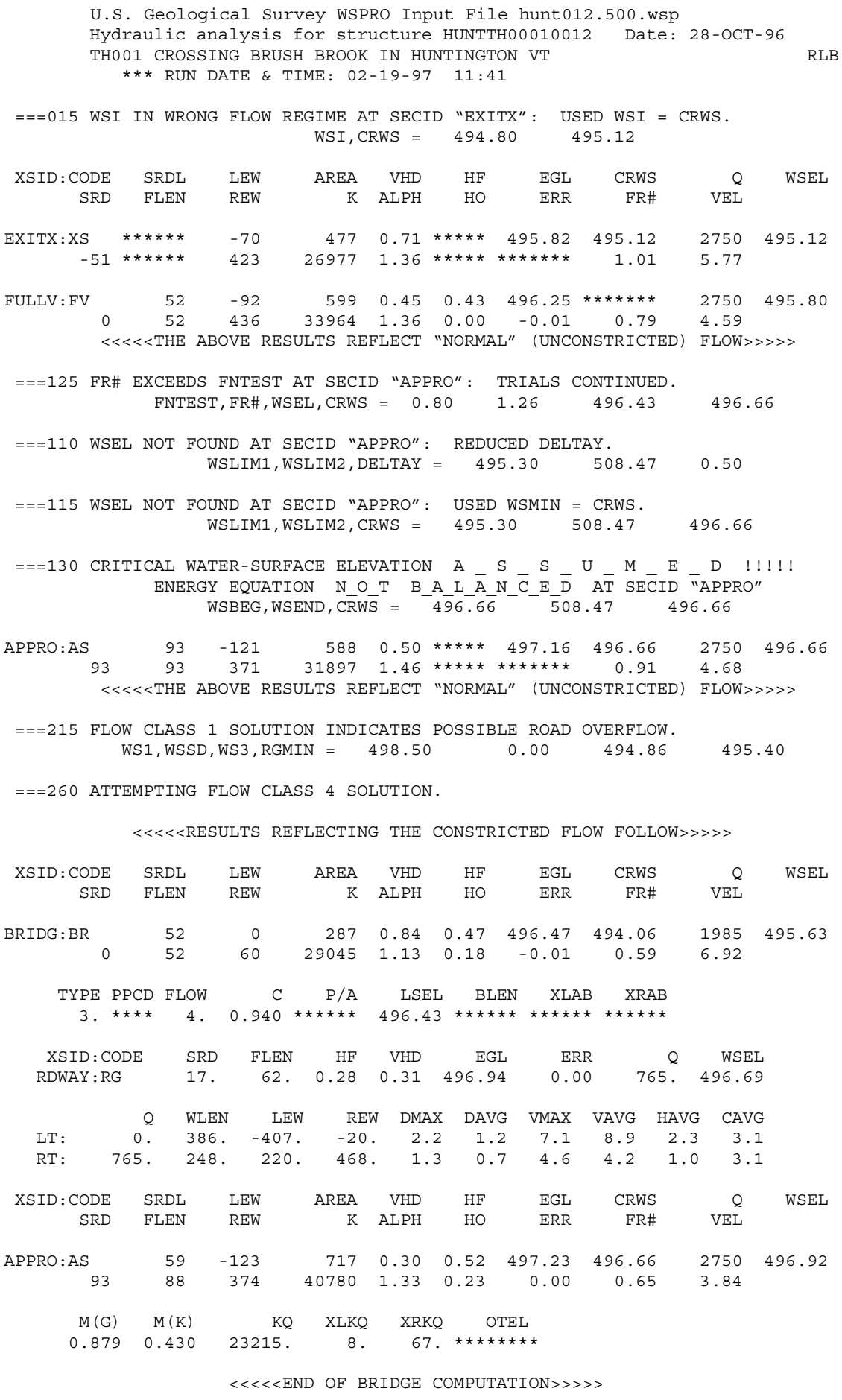

FIRST USER DEFINED TABLE.

\begin{tabular}{lrrrrrrrr} 
XSID : CODE & SRD & LEW & REW & $Q$ & K & AREA & VEL & WSEL \\
EXITX : XS & -52. & -71. & 423. & 2750. & 26977. & 477. & 5.77 & 495.12 \\
FULLV : FV & 0. & -93. & 436. & 2750. & 33964. & 599. & 4.59 & 495.80 \\
BRIDG : BR & 0. & 0. & 60. & 1985. & 29045. & 287. & 6.92 & 495.63 \\
RDWAY : RG & \multicolumn{1}{c}{$17 . * * * * * *$} & 0. & 765. & 0. & 0. & 1.00 & 496.69 \\
APPRO : AS & 93. & -124. & 374. & 2750. & 40780. & 717. & 3.84 & 496.92
\end{tabular}

SECOND USER DEFINED TABLE.

\begin{tabular}{|c|c|c|c|c|c|c|c|c|c|}
\hline XSID: CODE & CRWS & FR\# & YMIN & YMAX & $\mathrm{HF}$ & $\mathrm{HO}$ & VHD & EGL & \\
\hline EXITX:XS & 495.12 & 1.01 & 488.98 & $505.11 *$ & $\approx * \star \star \star \star \star *$ & $\approx * \star \star *$ & & 495.82 & 495.12 \\
\hline UL & $\star \star \star \star * \star *$ & & & & 0.43 & & & & \\
\hline & & & & & & & & & \\
\hline 1.10 & 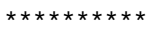 & 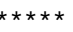 & & & $0.28 *$ & $\approx * \star * \star$ & 0.31 & 496.94 & 496.69 \\
\hline PPRO: AS & 496.66 & 0.65 & 489.74 & 508.47 & 0.52 & 0.23 & 0.30 & 497.23 & 496.92 \\
\hline
\end{tabular}




\section{APPENDIX C:}

\section{BED-MATERIAL PARTICAL-SIZE DISTRIBUTION}




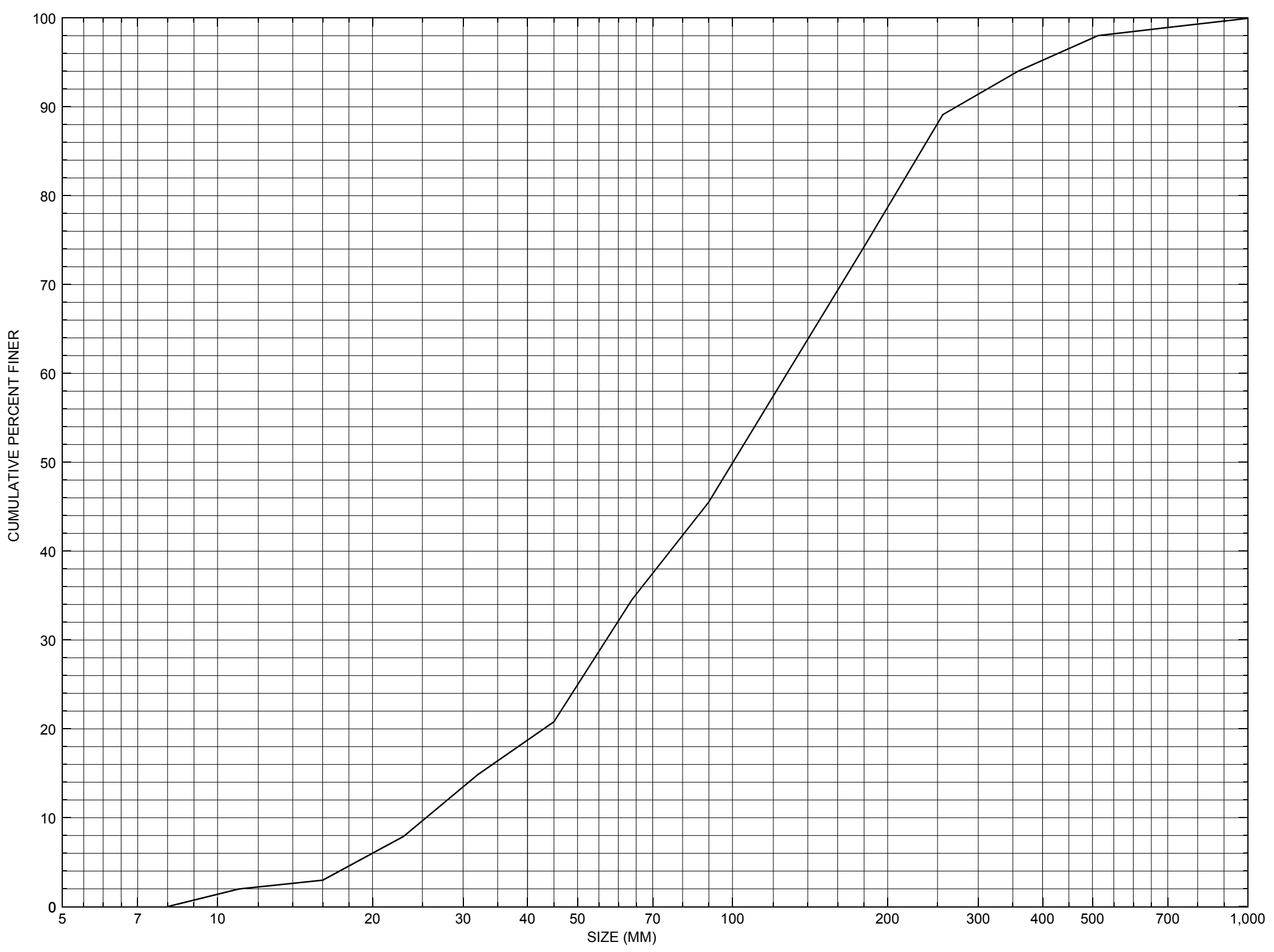

Appendix C. Bed material particle-size distribution for a pebble count at the approach cross-section for structure HUNTTH00010012, in Huntington, Vermont. 


\section{APPENDIX D: \\ HISTORICAL DATA FORM}




\section{Structure Number HUNTTH00010012}

\section{General Location Descriptive}

Data collected by (First Initial, Full last name) $\underline{\mathbf{L}}$. Medalie

Date $(M M / D D / Y Y) \_11 / 30$ / 95

Highway District Number $(I-2 ; n n) \underline{05}$

Town (FIPS place code; I - 4; nnnnn) $\mathbf{3 4 6 0 0}$

Waterway ( $($ - 6) BRUSH BROOK

Route Number -

Topographic Map Huntington

Latitude (I - 16; nnnn.n) 44179
County (FIPS county code; I - 3; nnn)

Mile marker (I- 11; nnn.nnn) $\underline{\mathbf{0 0 5 0 2 0}}$

Road Name (I - 7): TR 01 FAS 211

Vicinity (I - 9) 6.5 MI N JCT VT.17

Hydrologic Unit Code: $\mathbf{0 2 0 1 0 0 0 3}$

Longitude (i - 17; nnnnn.n) $\mathbf{7 2 5 8 1}$

\section{Select Federal Inventory Codes}

FHWA Structure Number $(I$ - 8) $\mathbf{2 0 0 2 1 1 0 0 1 2 0 4 0 8}$

Maintenance responsibility $(I-21 ; n n) \quad \mathbf{0 3}$

Year built (I - 27; YYYY) 1976

Average daily traffic, ADT (I - 29; nnnnnn) $\underline{\mathbf{0 0 1 0 7 0}}$

Year of ADT (I - 30; YY) $\mathbf{9 1}$

Opening skew to Roadway (I - 34; nn)

Operational status $(I-41 ; X) \quad \mathbf{A}$

Structure type (I - 43; nnn) $\mathbf{3 0 2}$

Approach span structure type $(I-44 ; n n n) \quad \mathbf{0 0 0}$

Number of spans (I - 45; nnn)

Number of approach spans (I - 46; nnnn) $\mathbf{0 0 0 0}$ Comments:

Structural inspection folder was missing from the regular 4th floor location at VT AOT.
Maximum span length (I - 48; nnnn) $\underline{\mathbf{0 0 6 2}}$

Structure length (I - 49; nnnnnn) $\underline{\mathbf{0 0 0 0 6 4}}$

Deck Width (I - 52; nn.n) $\mathbf{3 1 4}$

Channel \& Protection $(I-61 ; n) \underline{8}$

Waterway adequacy $(I-71 ; n) \underline{8}$

Underwater Inspection Frequency (I - 92B; XYY) _ N

Year Reconstructed (I - 106) $\mathbf{0 0 0 0}$

Clear span (nnn.nft) _

Vertical clearance from streambed (nnn.nft) -

Waterway of full opening (nnn.n $\left.\mathrm{ft}^{2}\right)$ 


\section{Bridge Hydrologic Data}

Is there hydrologic data available? $\underline{\mathbf{Y}}$ if No, type ctrl-n $h \quad$ VTAOT Drainage area $\left(\mathrm{mi}^{2}\right)^{2}: \underline{\mathbf{9 . 2}}$

Terrain character:

Stream character \& type: -

Streambed material:

Discharge Data (cfs):

$\mathrm{Q}_{2.33} \frac{\mathbf{7 5 0}}{\mathbf{1 8 5 0}}$

Record flood date $(M M / D D / Y Y):-$
Velocity at $\mathrm{Q}-$

$Q_{10} \frac{\mathbf{1 2 0 0}}{\mathbf{2 1 0 0}}$

$\mathrm{Q}_{25} \lcm{1550}$

$\mathrm{Q}_{500}$

Water surface elevation (ft): $(\mathrm{ft} / \mathrm{s}):$

Estimated Discharge (cfs): Debris (Heavy, Moderate, Light):

Ice conditions (Heavy, Moderate, Light) : -

The stage increases to maximum highwater elevation (Rapidly, Not rapidly):

The stream response is (Flashy, Not flashy):

Describe any significant site conditions upstream or downstream that may influence the stream's stage: -

Watershed storage area (in percent): ${ }_{-} \quad \%$

The watershed storage area is: - _ (1-mainly at the headwaters; 2- uniformly distributed; 3-immediatly upstream oi the site)

Water Surface Elevation Estimates for Existing Structure:

\begin{tabular}{|l|l|l|l|l|l|}
\hline Peak discharge frequency & $Q_{2.33}$ & $Q_{10}$ & $Q_{25}$ & $Q_{50}$ & $Q_{100}$ \\
Water surface elevation (ft)) & - & - & - & - & - \\
Velocity (ft/sec) & - & - & - & - & - \\
\hline
\end{tabular}

Long term stream bed changes: -

Is the roadway overtopped below the $\mathrm{Q}_{100}$ ? (Yes, No, Unknown): $\mathbf{U} \quad$ Frequency: -

Relief Elevation $(f t)$ :

Discharge over roadway at $Q_{100}\left(f^{3} / \mathrm{sec}\right)$ :

Are there other structures nearby? (Yes, No, Unknown): Upstream distance (miles): Town: If No or Unknown, type ctrl-n os

Highway No. : Structure No. : Year Built:

Clear span (ft): Clear Height (ft): Full Waterway $\left(f t^{2}\right)$ : 
Downstream distance (miles): Town: Year Built:

Highway No. : Structure No. : Structure Type:

Clear span (ft): Clear Height $(f t)$ : Full Waterway $\left(f t^{2}\right)$ :

Comments:

\section{USGS Watershed Data}

Watershed Hydrographic Data

Drainage area (DA) 9.19

Watershed storage (ST)

Bridge site elevation

Main channel length

690

4.98

$10 \%$ channel length elevation $\mathrm{mi}^{2}$ o $\%$

Lake and pond area

$\mathbf{0}$ $\mathrm{mi}^{2}$

Headwater elevation 4290 $\mathrm{ft}$ mi

Main channel slope $(S)$

(S) 469 750 $\mathrm{ft} \quad 85 \%$ channel length elevation $\mathrm{ft}$

Watershed Precipitation Data

Average site precipitation in Average headwater precipitation in

Maximum 2yr-24hr precipitation event $(124,2)$ in

Average seasonal snowfall (Sn) $\mathrm{ft}$ 


\section{Bridge Plan Data}

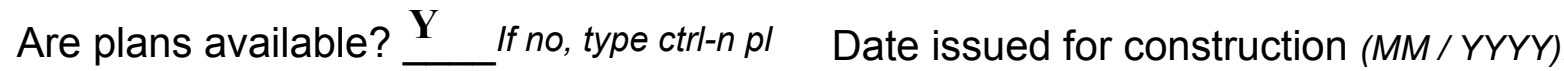

Project Number

Minimum channel bed elevation: $\underline{488.5}$

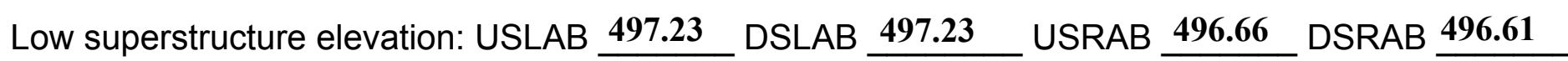

Benchmark location description:

BM \#1, S.I.R., 60" M assumed elev. 500', upstream edge of road, 200' left of bridge (next to gravel drive)

BM \#2, S.I.R., 4" M assumed elev. 496', upstream edge of road, 220' right of bridge

Reference Point (MSL, Arbitrary, Other):

Datum (NAD27, NAD83, Other):

Foundation Type: 1 (1-Spreadfooting; 2-Pile; 3- Gravity; 4-Unknown)

If 1: Footing Thickness $\mathbf{1 . 5}$ Footing bottom elevation: $\underline{\mathbf{4 8 9}}$

If 2: Pile Type: (1-Wood; 2-Steel or metal; 3-Concrete) Approximate pile driven length:

If 3: Footing bottom elevation:

Is boring information available? $\mathbf{Y}$ If no, type ctrl-n bi Number of borings taken: $\mathbf{2}$

Foundation Material Type: 1 (1-regolith, 2-bedrock, 3-unknown)

Briefly describe material at foundation bottom elevation or around piles:

Bottom of the footing of the Labut is in sandy gravel at 489.5 '.

Bottom of the footing of the Rabut is in silt at 489.0'.

Comments:

The low superstructure elevations are the bridge seat elevations from the bridge plans.

The elevation of the top wingwall-abutment corner is 501.5' on the left abutment US and DS, and 501.0' on the right abutment US and DS. 


\section{Cross-sectional Data}

Is cross-sectional data available? $\mathbf{N}$ If no, type ctrl-n xs

Source (FEMA, VTAOT, Other)? -

Comments: NO CROSS SECTIONAL INFORMATION

\begin{tabular}{|l|l|l|l|l|l|l|l|l|l|l|l|}
\hline Station & & - & - & - & - & - & - & - & - & - & - \\
\hline Feature & - & - & - & - & - & - & - & - & - & - & - \\
\hline $\begin{array}{l}\text { Low cord } \\
\text { elevation }\end{array}$ & - & - & - & - & - & - & - & - & - & - & - \\
\hline $\begin{array}{l}\text { Bed } \\
\text { elevation }\end{array}$ & - & - & - & - & - & - & - & - & - & - & - \\
\hline $\begin{array}{l}\text { Low cord to } \\
\text { bed length }\end{array}$ & - & - & - & - & - & - & - & - & - & - & - \\
\hline Station & - & - & - & - & - & - & - & - & - & - & - \\
\hline Feature & - & - & - & - & - & - & - & - & - & - & - \\
\hline $\begin{array}{l}\text { Low cord } \\
\text { elevation }\end{array}$ & - & - & - & - & - & - & - & - & - & - & - \\
\hline $\begin{array}{l}\text { Bed } \\
\text { elevation }\end{array}$ & - & - & - & - & - & - & - & - & - & - & - \\
\hline $\begin{array}{l}\text { Low cord to } \\
\text { bed length }\end{array}$ & - & - & - & - & - & - & - & - & - & - & - \\
\hline
\end{tabular}

Source (FEMA, VTAOT, Other)?

Comments: -

\begin{tabular}{|l|l|l|l|l|l|l|l|l|l|l|l|}
\hline Station & & - & - & - & - & - & - & - & - & - & - \\
\hline Feature & - & - & - & - & - & - & - & - & - & - & - \\
\hline $\begin{array}{l}\text { Low cord } \\
\text { elevation }\end{array}$ & - & - & - & - & - & - & - & - & - & - & - \\
\hline $\begin{array}{l}\text { Bed } \\
\text { elevation }\end{array}$ & - & - & - & - & - & - & - & - & - & - & - \\
\hline $\begin{array}{l}\text { Low cord to } \\
\text { bed length }\end{array}$ & - & - & - & - & - & - & - & - & - & - & - \\
\hline Station & - & - & - & - & - & - & - & - & - & - & - \\
\hline Feature & - & - & - & - & - & - & - & - & - & - & - \\
\hline $\begin{array}{l}\text { Low cord } \\
\text { elevation }\end{array}$ & - & - & - & - & - & - & - & - & - & - & - \\
\hline $\begin{array}{l}\text { Bed } \\
\text { elevation }\end{array}$ & - & - & - & - & - & - & - & - & - & - & - \\
\hline $\begin{array}{l}\text { Low cord to } \\
\text { bed length }\end{array}$ & - & - & - & - & - & - & - & - & - & - & - \\
\hline
\end{tabular}




\section{APPENDIX E: \\ LEVEL I DATA FORM}


U. S. Geological Survey

Bridge Field Data Collection and Processing Form

Qa/Qc Check by: $\underline{\mathbf{R B}}$ Date: $10 / 28 / 96$

\section{Structure Number}

HUNTTH00010012

Computerized by: $\underline{\mathbf{R B}}$ Date: $10 / 29 / 96$

Reviewd by: SAO Date: $\mathbf{0 3 / 1 3 / 9 7}$

\section{A. General Location Descriptive}

1. Data collected by (First Initial, Full last name) E. WILD

2. Highway District Number $\mathbf{0 5}$

County 007

Waterway (I - 6) BRUSH BROOK

Route Number -

Date $(M M / D D / Y Y) \underline{06} / \underline{25} / \underline{1996}$

. Descriptive comments:

Located 6.5 miles north of the junction with VT 17.

Mile marker $\mathbf{0 0 5 0 2 0}$

Town 34600

Road Name TR01 FAS 211

Hydrologic Unit Code: $\mathbf{0 2 0 1 0 0 0 3}$

\section{B. Bridge Deck Observations}

\section{Surface cover... LBUS 4 \\ RBUS 4 \\ LBDS 4 \\ RBDS 4 \\ Overall 4}

(2b us, ds,lb,rb: 1- Urban; 2- Suburban; 3- Row crops; 4- Pasture; 5- Shrub- and brushland; 6- Forest; 7- Wetland)
5. Ambient water surface... US 2
UB 1 DS 2
(1- pool; 2- riffle)

6. Bridge structure type 1 (1- single span; 2- multiple span; 3- single arch; 4- multiple arch; 5-cylindrical culvert; 6- box culvert; or 7- other)
7. Bridge length 64
(feet)
Span length 62
(feet)
Bridge width 31.4 (feet)

\section{Road approach to bridge:}
8. LB 1 RB 1
( 0 even, 1- lower, 2- higher)
9. LB 1 RB 1
(1-Paved, 2- Not paved)

10. Embankment slope (run / rise in feet / foot)

$$
\text { US left }
$$

2.9:1

US right

4.7:1

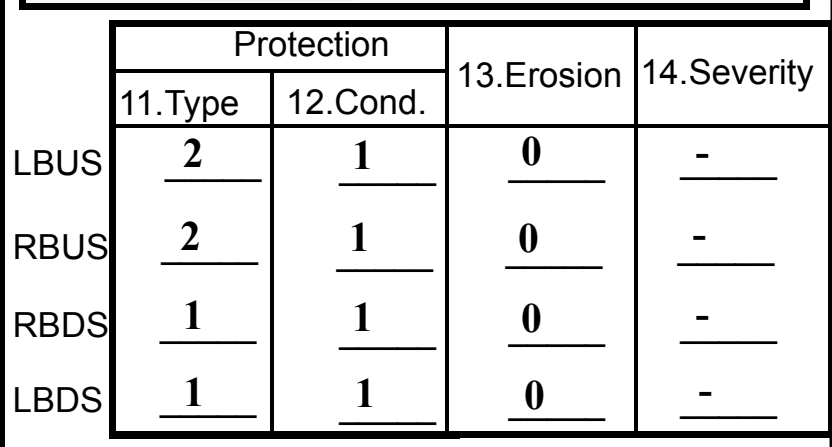

Bank protection types: 0- none; 1- $<12$ inches;

$$
\text { 2- < } 36 \text { inches; 3- < } 48 \text { inches; }
$$

4- $<60$ inches; 5- wall / artificial levee

Bank protection conditions: 1- good; 2- slumped;

3- eroded; 4- failed

Erosion: 0 - none; 1- channel erosion; 2 -

road wash; 3- both; 4- other

Erosion Severity: 0 - none; 1- slight; 2- moderate; 3- severe

\section{Channel approach to bridge (BF):}

15. Angle of approach: $\mathbf{5}$

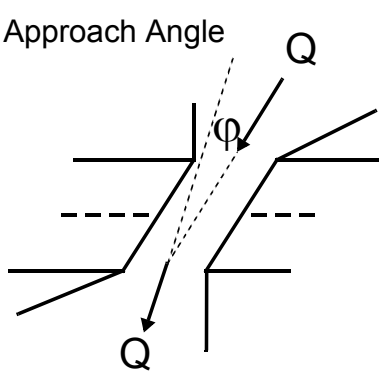

17. Channel impact zone 1 :

Where? LB $(L B, R B)$

Range? 86 feet DS

Channel impact zone 2:

Where? _ _ $(L B, R B)$

Range? - $\quad$ feet -

(US, UB, DS) to Impact Severity: 0- none to very slight; 1- Slight; 2- Moderate; 3- Severe feet -

16. Bridge skew: 10 Bridge Skew Angle

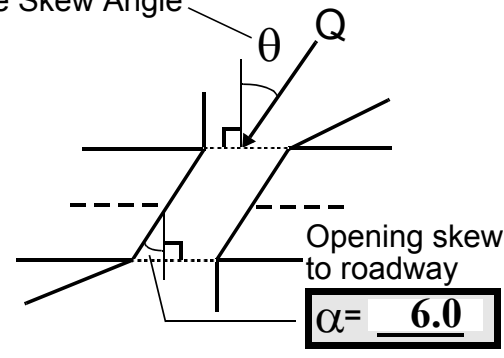

\section{Exist? $\mathbf{Y}(Y$ or $N)$}

Severity 1

(US, UB, DS) to $\underline{\mathbf{3 6 0}}$ feet $\underline{\mathbf{D S}}$

Exist? $\mathbf{N}(Y$ or $N)$

Severity - 
18. Bridge Type: $1 \mathbf{1 a / 3}$

1a- Vertical abutments with wingwalls

1 b- Vertical abutments without wingwalls

2- Vertical abutments and wingwalls, sloping embankment Wingwalls perpendicular to abut. face

3- Spill through abutments

4- Sloping embankment, vertical wingwalls and abutments

Wingwall angle less than $90^{\circ}$.

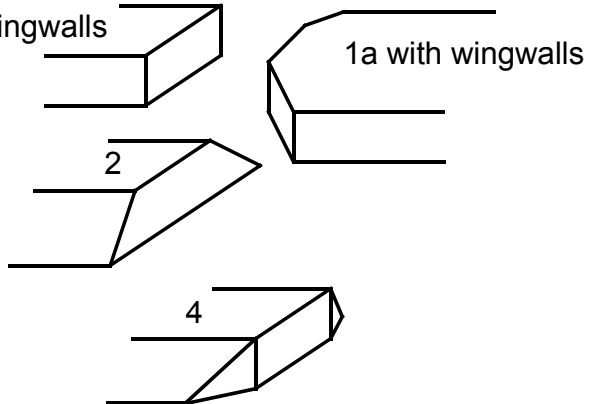

19. Bridge Deck Comments (surface cover variations, measured bridge and span lengths, bridge type variations, approach overflow width, etc.)

4. The left bank US is vegetated with brush and a few trees along the channel and a field with 3 houses and a swing set on the overbank. The right bank US has brush along the channel and a field on the overbank with one large and one small barn. The right bank DS is a field with one house about $200 \mathrm{ft}$. from the bridge and brush along the bank. The left bank DS has brush and a few trees along the channel and a barn across from the US left bank houses.

18. The wingwalls are parallel to the abutments, but do not go below low chord. Also, the protection around the abutments act like a spill through type abutment.

\section{Upstream Channel Assessment}

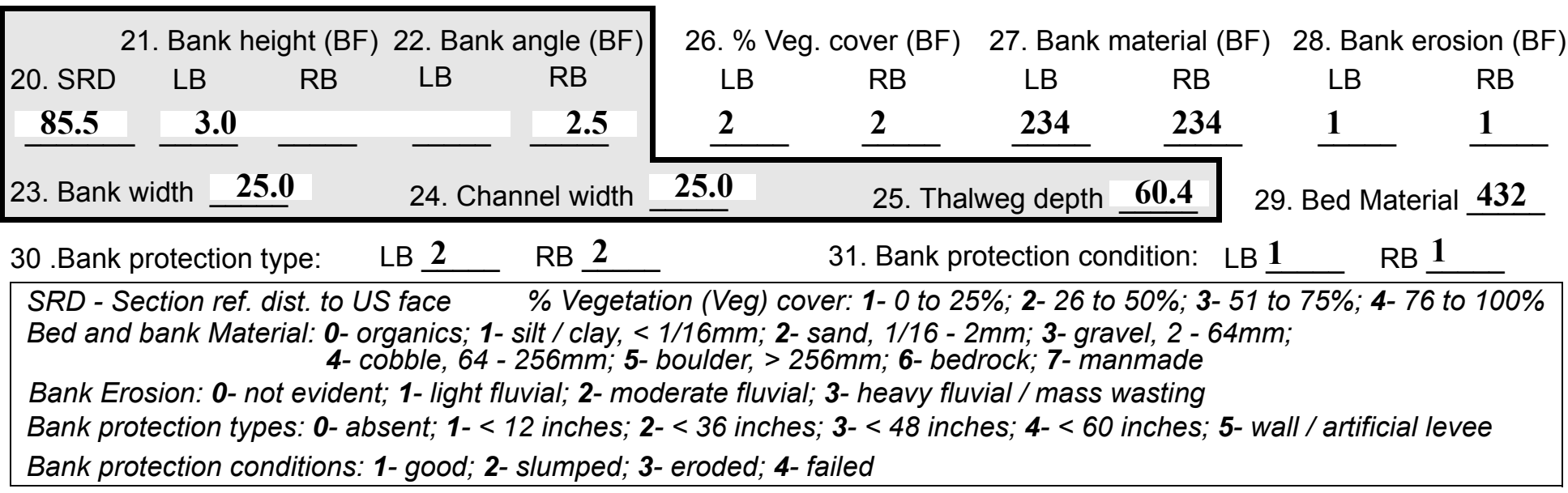

32. Comments (bank material variation, minor inflows, protection extent, etc.):

From $175 \mathrm{ft}$. US to $130 \mathrm{ft}$. US the left bank point bar is slightly eroded where two $0.3 \mathrm{ft}$. diameter birch trees now exist horizontally in the channel.

30. The bank protection extends from the end of the wingwalls to about $200 \mathrm{ft}$. US. The banks are well protected and constrict the channel. 
37. Material: $\mathbf{2 4 3}$

38. Point or side bar comments (Circle Point or Side; Note additional bars, material variation, status, etc.):

This side bar is vegetated with clumps of grass along the channel and trees along the banks on both the US and DS ends, however, under the bridge the bar is only comprised of sand. Another side bar comprised of cobble, gravel, and sand exists from $170 \mathrm{ft}$. US to $125 \mathrm{ft}$. US. It is positioned from $50 \% \mathrm{LB}$ to $100 \% \mathrm{RB}$ with a mid-bar width of $40.5 \mathrm{ft}$. at $133 \mathrm{ft}$. US. This bar is vegetated with grass clumps on the streamward side and trees and bushes on the bankward side.

39. Is a cut-bank present? $\mathbf{N}$ ( $Y$ or if $N$ type ctrl-n cb)

40. Where? (LB or $R B)$

41. Mid-bank distance: -

42. Cut bank extent: (US, UB) to feet (US, UB, DS)

43. Bank damage: (1- eroded and/or creep; 2- slip failure; 3- block failure)

44. Cut bank comments (eg. additional cut banks, protection condition, etc.):

NO CUT BANKS

45. Is channel scour present? $\mathbf{Y}$ ( $Y$ or if $N$ type ctrl-n cs)

47. Scour dimensions: Length $\mathbf{9 5}$ Width 4.2 Depth : $\mathbf{2 . 2}$

46. Mid-scour distance: $\mathbf{7 4}$

48. Scour comments (eg. additional scour areas, local scouring process, etc.):

Scour is from $80 \mathrm{ft}$. US to $15 \mathrm{ft}$. under the bridge. Thalweg depth is assumed to be $0.5 \mathrm{ft}$. An additional scour hole is from $128 \mathrm{ft}$. US to $121 \mathrm{ft}$. US. It is $7 \mathrm{ft}$. in length and $4.5 \mathrm{ft}$. wide and has a depth of $0.6 \mathrm{ft}$. It is positioned from $30 \%$ LB to $50 \%$ RB with mid-scour at $124 \mathrm{ft}$. US.

\section{Are there major confluences? $\mathbf{N}$}

51. Confluence 1: Distance Confluence 2: Distance 52. Enters on Enters on 54. Confluence comments (eg. confluence name):

\section{NO MAJOR CONFLUENCES}

50. How many? -

53. Type-_ (1- perennial; 2- ephemeral)
Type - (1- perennial; 2- ephemeral) (LB or $R B)$ (LB or $R B)$

\section{Under Bridge Channel Assessment}

55. Channel restraint (BF)? LB 2

\begin{tabular}{|ccccc}
\hline \multicolumn{2}{|c}{ 56. Height (BF) } & \multicolumn{3}{c}{57 Angle (BF) } \\
LB & RB & LB & RB \\
$\mathbf{4 3 . 0}$ & & & $\mathbf{1 . 0}$ & \\
\hline
\end{tabular}
(1- natural bank; 2- abutment; 3- artificial levee)

58. Bank width (BF) 59. Channel width (Amb) \begin{tabular}{lc} 
61. Material (BF) \\
LB & RB \\
$\mathbf{2}$ & $\mathbf{7}$ \\
\hline
\end{tabular} 62. Erosion (BF) LB RB 7 63. Bed Material -

Bed and bank Material: 0- organics; 1- silt / clay, < 1/16mm; 2- sand, 1/16 - 2mm; 3- gravel, 2 - 64mm; 4- cobble, 64 - 256mm; 5- boulder, > 256mm; 6- bedrock; 7- manmade

Bank Erosion: 0- not evident; 1- light fluvial; 2- moderate fluvial; 3- heavy fluvial / mass wasting

64. Comments (bank material variation, minor inflows, protection extent, etc.):

432

Channel scour exists along the bottom of the spill-through on the right side.

63. The stream bed is uniform, tightly packed cobbles. 
65. Debris and Ice Is there debris accumulation?

(Yor $N)$ 66. Where? $\underline{Y}$

(1- Upstream; 2- At bridge; 3- Both)

67. Debris Potential $\underline{1}$ (1-Low; 2- Moderate; 3- High)

68. Capture Efficiency 1 (1-Low; 2- Moderate; 3- High)

69. Is there evidence of ice build-up? 1 (Y or $N)$

Ice Blockage Potential $\mathbf{N}$

(1-Low; 2- Moderate; 3- High)

70. Debris and Ice Comments:

1

66. Debris has accumulated on the side bars between bushes and trees as well as on the DS point bar.

67. Debris potential is low due to the surface area being pasture and the only vegetation being along the channel.

\begin{tabular}{|l|c|c|c|c|c|c|c|c|}
\hline Abutments & $\begin{array}{c}\text { 71. Attack } \\
\angle \text { (BF) }\end{array}$ & $\begin{array}{c}72 \text {. Slope } \angle \\
\text { (Qmax) }\end{array}$ & $\begin{array}{c}\text { 73. Toe } \\
\text { loc. (BF) }\end{array}$ & $\begin{array}{c}\text { 74. Scour } \\
\text { Condition }\end{array}$ & $\begin{array}{c}75 . \text { Scour } \\
\text { depth }\end{array}$ & $\begin{array}{c}\text { 76. Exposure } \\
\text { depth }\end{array}$ & 77. Material & 78. Length \\
\hline LABUT & & $\mathbf{5}$ & $\mathbf{9 0}$ & $\mathbf{0}$ & $\mathbf{0}$ & - & - & $\mathbf{9 0 . 0}$ \\
\hline RABUT & $\mathbf{1}$ & $\mathbf{0}$ & $\mathbf{9 0}$ & & & $\mathbf{0}$ & $\mathbf{0}$ & $\mathbf{5 9 . 5}$ \\
\hline
\end{tabular}

Pushed: $L B$ or RB

Toe Location (Loc.): 0- even, 1- set back, 2- protrudes

Scour cond.: 0- not evident; 1- evident (comment); 2- footing exposed; 3-undermined footing; 4- piling exposed; 5- settled; 6- failed

Materials: 1- Concrete; 2- Stone masonry or drywall; 3- steel or metal; 4- wood

79. Abutment comments (eg. undermined penetration, unusual scour processes, debris, etc.):

$-$

1

The abutments are in good condition. The water level only reaches the abutments at bankfull because of the protection. There are high water marks on both banks US and DS.

80. Wingwalls:

Exist? Material? Scour Scour Exposure $\begin{aligned} & 81 . \\ & \text { Angle? Length? }\end{aligned}$ Condition? depth? depth?

USLWW:

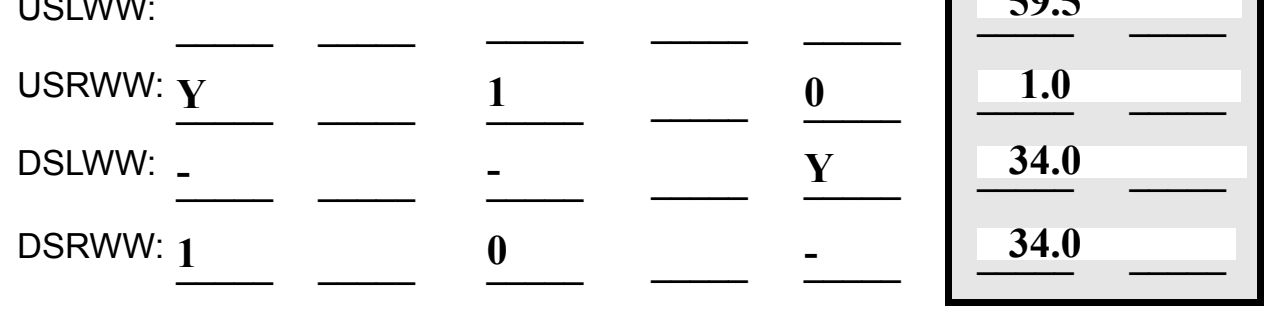

Wingwall materials: 1- Concrete; 2- Stone masonry or drywall; 3- steel or metal; 4- wood

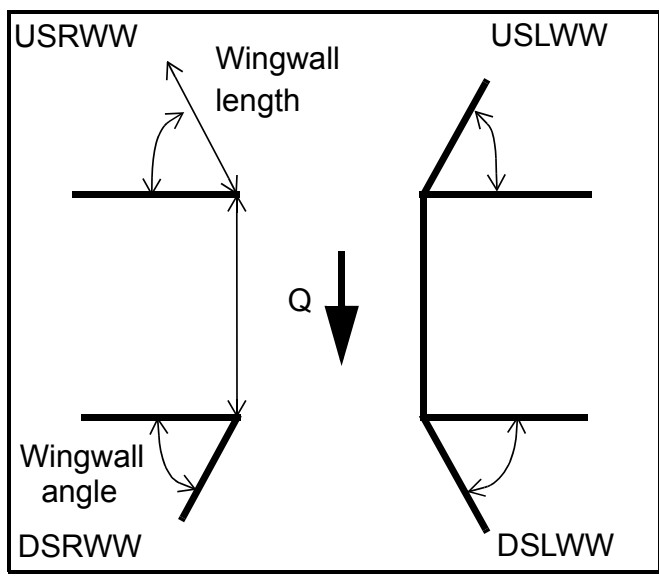

82. Bank / Bridge Protection:

\begin{tabular}{|l|l|l|l|l|l|l|l|c|}
\hline Location & USLWW & USRWW & LABUT & RABUT & LB & RB & DSLWW & DSRWW \\
\hline Type & - & $\mathbf{0}$ & $\mathbf{Y}$ & - & $\mathbf{1}$ & $\mathbf{1}$ & $\mathbf{1}$ & $\mathbf{1}$ \\
\hline Condition & $\mathbf{Y}$ & - & $\mathbf{1}$ & - & $\mathbf{1}$ & $\mathbf{1}$ & $\mathbf{1}$ & $\mathbf{1}$ \\
\hline Extent & $\mathbf{1}$ & - & $\mathbf{0}$ & $\mathbf{2}$ & $\mathbf{2}$ & $\mathbf{3}$ & $\mathbf{3}$ & - \\
\hline
\end{tabular}

Bank / Bridge protection types: 0- absent; 1- < 12 inches; 2- < 36 inches; 3- < 48 inches; 4- < 60 inches; 
83. Wingwall and protection comments (eg. undermined penetration, unusual scour processes, etc.):

-
-
-
-
-
2
1
1
2
1
1

Piers:

84. Are there piers? Th (Y or if N type ctrl-n pr)

\begin{tabular}{|l|l|l|l|l|l|l|l|}
\hline \multirow{2}{*}{$\begin{array}{l}85 . \\
\text { Pier no. }\end{array}$} & \multicolumn{3}{|c|}{ width (w) feet } & \multicolumn{3}{c|}{ elevation (e) feet } \\
\cline { 2 - 9 } & w1 & w2 & w3 & e@w1 & e@w2 & e@w3 \\
\hline Pier 1 & $\mathbf{9 5 . 0}$ & $\mathbf{8 5 . 0}$ & $\mathbf{8 5 . 0}$ & $\mathbf{8 . 0}$ & $\mathbf{8 . 0}$ & $\mathbf{8 . 0}$ \\
\hline Pier 2 & $\mathbf{9 5 . 0}$ & - & - & $\mathbf{8 . 0}$ & - & - & - \\
\hline Pier 3 & - & - & - & - & - & - \\
\hline Pier 4 & - & - & - & - & - & - \\
\hline
\end{tabular}

\begin{tabular}{|l|l|l|l|l|}
\hline Level 1 Pier Descr. & \multicolumn{1}{|c|}{1} & \multicolumn{1}{|c|}{2} & \multicolumn{1}{|c|}{3} & \multicolumn{1}{|c|}{} \\
\hline 86. Location (BF) & ere & both & $\mathbf{8 2 .}$ & s. \\
\hline 87. Type & are & the & All & The \\
\hline 88. Material & Ver- & US & four & pro- \\
\hline 89. Shape & mont & left & wing & tec- \\
\hline 90. Inclined? & sur- & wing & walls & tion \\
\hline 91. Attack $\angle$ (BF) & vey & wall & are & acts \\
\hline 92. Pushed & mar & and & par- & like \\
\hline 93. Length (feet) & - & - & - & - \\
\hline 94. \# of piles & ks, & the & allel & a \\
\hline 95. Cross-members & meta & DS & to & spill \\
\hline 96. Scour Condition & l & right & the & thro \\
\hline 97. Scour depth & disks & wing & abut & ugh \\
\hline 98. Exposure depth & on & wall. & ment & type \\
\hline
\end{tabular}

LFP, LTB, LB, MCL, MCM, MCR, RB, RTB, RFP

1- Solid pier, 2- column, 3- bent

1-Wood; 2-concrete; 3- metal; 4- stone

1- Round; 2- Square; 3- Pointed

Y-yes; $N$ - no

$L B$ or $R B$

0- none; 1- laterals; 2- diagonals; 3- both

0- not evident; 1- evident (comment);

2- footing exposed; 3- piling exposed;

4- undermined footing; 5- settled; 6- failed 
99. Pier comments (eg. undermined penetration, protection and protection extent, unusual scour processes, etc.): abutment.

100.

\section{E. Downstream Channel Assessment}

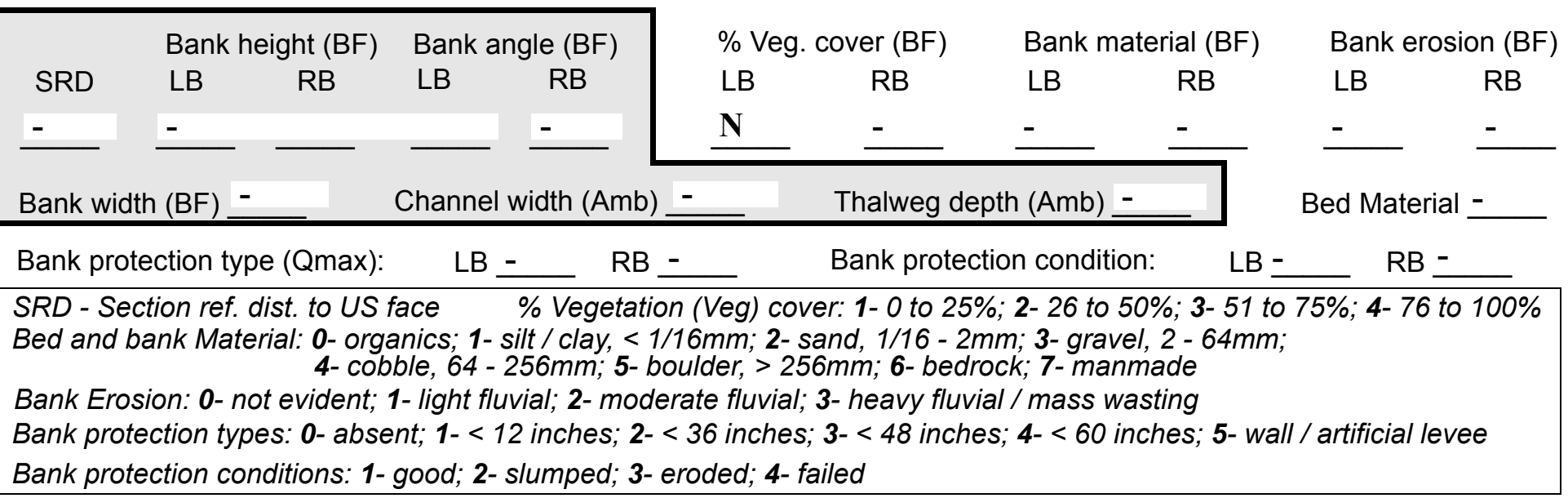

Comments (eg. bank material variation, minor inflows, protection extent, etc.):

$-$

$-$

$-$

$-$

$-$

$-$

$-$

$-$

$-$

$-$

$-$

$-$

$-$

$-$

\section{Is a drop structure present? __ ( $Y$ or $N$, if $N$ type ctrl-n $d s) \quad$ 102. Distance: ___ feet}

103. Drop: -_ feet 104. Structure material: __ (1- steel sheet pile; 2- wood pile; 3- concrete; 4- other)

105. Drop structure comments (eg. downstream scour depth):

$-$

$-$

$-$

-

$-$ 
106. Point/Side bar present? (Y or $N$. if $N$ type ctrl-n pb)Mid-bar distance:

Mid-bar width: -

Point bar extent: feet -

(US, UB, DS) to feet (US, UB, DS) positioned $\%$ LB to $\% \mathrm{RB}$ Material:

Point or side bar comments (Circle Point or Side; note additional bars, material variation, status, etc.):

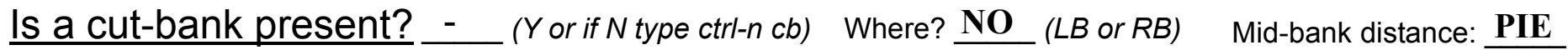

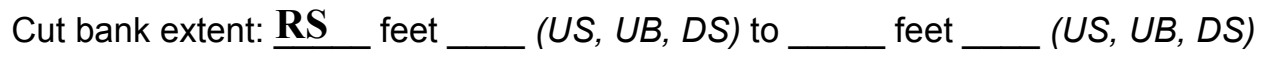

Bank damage: __ (1- eroded and/or creep; 2- slip failure; 3- block failure)

Cut bank comments (eg. additional cut banks, protection condition, etc.):

Is channel scour present? Scour dimensions: Length 1 Width 234 Depth: 234 Scour comments (eg. additional scour areas, local scouring process, etc.): 43

0

0

Are there major confluences?

Confluence 1: Distance the

Confluence 2: Distance bank ( $Y$ or if $N$ type ctrl-n $m c)$ Enters on $\underline{\text { righ }}$ ( $L B$ or $R B)$ Enters on ther ( $L B$ or $R B)$

Confluence comments (eg. confluence name):

crushed stone and boulders placed in front of the concrete blocks surrounding a dry hydrant. The DS cross section was surveyed a few feet DS of the dry hydrant blocks.

\section{F. Geomorphic Channel Assessment}

107. Stage of reach evolution

1- Constructed

2- Stable

3- Aggraded

4- Degraded

5- Laterally unstable

6- Vertically and laterally unstable 
108. Evolution comments (Channel evolution not considering bridge effects; See HEC-20, Figure 1 for geomorphic descriptors): 


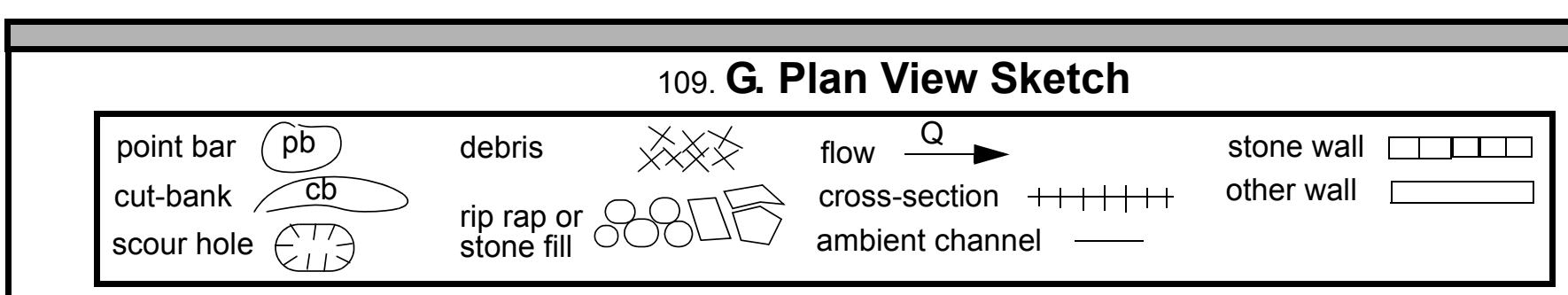


APPENDIX F:

SCOUR COMPUTATIONS 


\begin{tabular}{|c|c|c|c|}
\hline Structure Number: HUNTTH00010012 & & Town: & Huntington \\
\hline Road Number: $\quad 1$ & & County: & Chittenden \\
\hline Brush Brook & & & \\
\hline Initials RLB & Checked: & SAO & \\
\hline Analysis of contraction scour, live & -bed or $\mathrm{C}$. & lear wat & \\
\hline $\begin{array}{l}\text { Critical Velocity of Bed Material } \\
\mathrm{VC}=11.21 * \mathrm{Y}^{\wedge} 0.1667 * \mathrm{D} 50^{\wedge} 0.33 \text { with } \mathrm{S}\end{array}$ & $\begin{array}{l}\text { converted } \\
=2.65\end{array}$ & to Engl & sh units) \\
\hline Approach Section & & & \\
\hline Characteristic & $100 \mathrm{yr}$ & $500 \mathrm{yr}$ & other $Q$ \\
\hline Total discharge, cfs & 2100 & 2750 & 0 \\
\hline Main Channel Area, ft2 & 279 & 307 & 0 \\
\hline Left overbank area, ft2 & 45 & 101 & 0 \\
\hline Right overbank area, ft2 & 26 & 307 & 0 \\
\hline Top width main channel, ft & 60 & 60 & 0 \\
\hline Top width L overbank, ft & 120 & 124 & 0 \\
\hline Top width $\mathrm{R}$ overbank, ft & 106 & 313 & 0 \\
\hline D50 of channel, ft & 0.328 & 0.328 & 0 \\
\hline D50 left overbank, ft & -- & -- & -- \\
\hline D50 right overbank, ft & -- & -- & -- \\
\hline Y1, average depth, MC, ft & 4.7 & 5.1 & ERR \\
\hline y1, average depth, LOB, ft & 0.4 & 0.8 & ERR \\
\hline $\mathrm{y}_{1}$, average depth, ROB, ft & 0.2 & 1.0 & ERR \\
\hline Total conveyance, approach & 21908 & 40668 & 0 \\
\hline Conveyance, main channel & 20479 & 23994 & 0 \\
\hline Conveyance, LOB & 1007 & 3770 & 0 \\
\hline Conveyance, ROB & 422 & 12904 & 0 \\
\hline Percent discrepancy, conveyance & 0.0000 & 0.0000 & $\mathrm{ERR}$ \\
\hline Qm, discharge, MC, cfs & 1963.0 & 1622.5 & ERR \\
\hline Q1, discharge, LOB, cfs & 96.5 & 254.9 & ERR \\
\hline Qr, discharge, ROB, Cfs & 40.5 & 872.6 & ERR \\
\hline Vm, mean velocity $M C$, ft/s & 7.0 & 5.3 & ERR \\
\hline Vl, mean velocity, LOB, ft/s & 2.1 & 2.5 & ERR \\
\hline Vr, mean velocity, ROB, ft/s & 1.6 & 2.8 & ERR \\
\hline Vc-m, crit. velocity, $M C$, ft/s & 10.0 & 10.1 & $\mathrm{~N} / \mathrm{A}$ \\
\hline Vc-l, crit. velocity, LOB, ft/s & $\mathrm{ERR}$ & $\mathrm{ERR}$ & ERR \\
\hline Vc-r, crit. velocity, ROB, ft/s & ERR & ERR & ERR \\
\hline Results & & & \\
\hline Live-bed(1) or Clear-Water(0) Cont & action $\mathrm{ScC}$ & our? & \\
\hline Main Channel & 0 & 0 & $\mathrm{~N} / \mathrm{A}$ \\
\hline Left Overbank & $\mathrm{N} / \mathrm{A}$ & $\mathrm{N} / \mathrm{A}$ & $\mathrm{N} / \mathrm{A}$ \\
\hline Right Overbank & $\mathrm{N} / \mathrm{A}$ & $\mathrm{N} / \mathrm{A}$ & $\mathrm{N} / \mathrm{A}$ \\
\hline
\end{tabular}


Clear Water Contraction Scour in MAIN CHANNEL

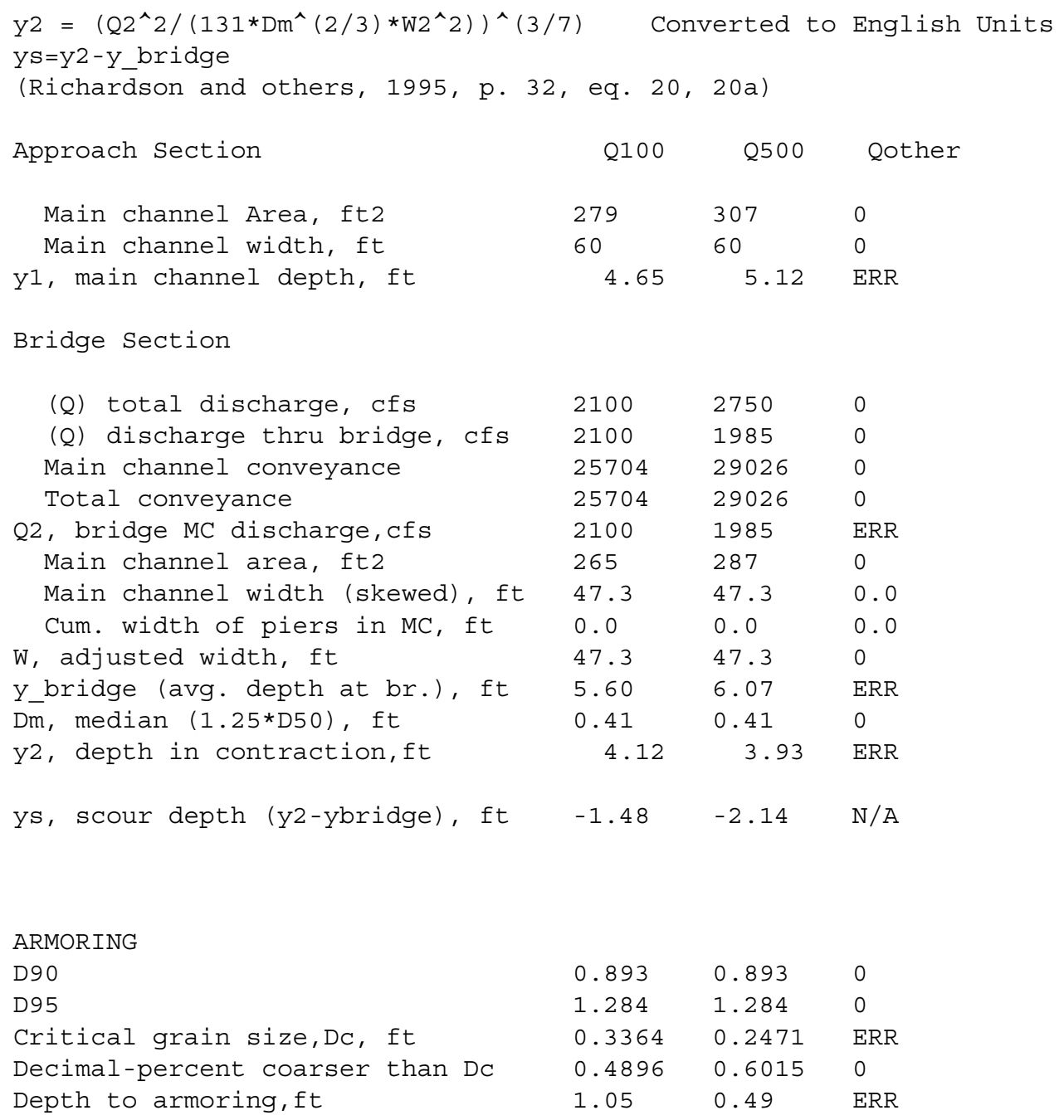


Abutment Scour

Froehlich's Abutment Scour

$\mathrm{Ys} / \mathrm{Y} 1=2.27 * \mathrm{~K} 1 * \mathrm{~K} 2 *\left(\mathrm{a}^{\prime} / \mathrm{Y} 1\right) \wedge 0.43 * \mathrm{Fr} 1 \wedge 0.61+1$

(Richardson and others, 1995, p. 48, eq. 28)

\begin{tabular}{|c|c|c|c|c|c|c|}
\hline \multirow[b]{2}{*}{ Characteristic } & \multicolumn{2}{|c|}{ Left Abutment } & \multicolumn{4}{|c|}{ Right Abutment } \\
\hline & \multicolumn{3}{|c|}{100 yr Q 500 yr Q Other } & \multicolumn{2}{|c|}{100 yr Q 500 yr } & ther $Q$ \\
\hline (Qt), total discharge, cfs & 2100 & 2750 & 0 & 2100 & 2750 & 0 \\
\hline a', abut.length blocking flow, ft & 124.5 & 128.9 & 0 & 114.8 & 85.6 & 0 \\
\hline Ae, area of blocked flow ft2 & 57.13 & 114.56 & 0 & 43.62 & 80.8 & 0 \\
\hline Qe, discharge blocked abut., cfs & 152.58 & 301.37 & 0 & 113.08 & -- & 0 \\
\hline (If using Qtotal_overbank to obt & $\operatorname{ain} \mathrm{Ve}$, & ave Qe b & ank an & nter $\mathrm{Ve}$ & id Fr $\mathrm{F}$ & dally) \\
\hline Ve, $(Q e / A e), f t / s$ & 2.67 & 2.63 & ERR & 2.59 & 2.36 & ERR \\
\hline ya, depth of $f / p$ flow, ft & 0.46 & 0.89 & ERR & 0.38 & 0.94 & ERR \\
\hline --Coeff., K1, for abut. type (1.0, & verti.; & .82 , ver & i. w/ & gwall; & 55, spj & thru) \\
\hline $\mathrm{K} 1$ & 0.55 & 0.55 & 0 & 0.55 & 0.55 & 0 \\
\hline --Angle (theta) of embankment $(<90$ & if abut & points $D$ & $i>90$ & abut. pc & ats US) & \\
\hline theta & 95 & 95 & 0 & 85 & 85 & 0 \\
\hline $\mathrm{K} 2$ & 1.01 & 1.01 & 0.00 & 0.99 & 0.99 & 0.00 \\
\hline Fr, froude number $f / p$ flow & 0.695 & 0.492 & ERR & 0.741 & 0.428 & ERR \\
\hline ys, scour depth, ft & 5.60 & 7.05 & $\mathrm{~N} / \mathrm{A}$ & 4.95 & 5.79 & $\mathrm{~N} / \mathrm{A}$ \\
\hline \multicolumn{7}{|c|}{ HIRE equation $\left(a^{\prime} /\right.$ ya $\left.>25\right)$} \\
\hline \multicolumn{7}{|c|}{$\begin{array}{l}\mathrm{ys}=4 * \mathrm{Fr}^{\wedge} 0.33 * \mathrm{Y} 1 * \mathrm{~K} / 0.55 \\
(\text { Richardson and others, 1995, p. 49, eq. 29) }\end{array}$} \\
\hline$a^{\prime}$ (abut length blocked, ft) & 124.5 & 128.9 & 0 & 114.8 & 85.6 & 0 \\
\hline y1 (depth f/p flow, ft) & 0.46 & 0.89 & ERR & 0.38 & 0.94 & ERR \\
\hline$a^{\prime} / y 1$ & 271.32 & 145.04 & ERR & 302.13 & 90.69 & $\mathrm{ERR}$ \\
\hline Skew correction (p. 49, fig. 16) & 1.01 & 1.01 & 1.01 & 0.98 & 0.98 & 0.98 \\
\hline Froude no. $\mathrm{f} / \mathrm{p}$ flow & 0.69 & 0.49 & $\mathrm{~N} / \mathrm{A}$ & 0.74 & 0.43 & $\mathrm{~N} / \mathrm{A}$ \\
\hline \multirow{3}{*}{$\begin{array}{l}\text { Ys w/ corr. factor K1/0.55: } \\
\text { vertical } \\
\text { vertical w/ ww's } \\
\text { spill-through }\end{array}$} & 2.99 & 5.17 & ERR & 2.46 & 5.10 & ERR \\
\hline & 2.45 & 4.24 & ERR & 2.02 & 4.18 & $\mathrm{ERR}$ \\
\hline & 1.65 & 2.84 & ERR & 1.35 & 2.80 & ERR \\
\hline
\end{tabular}




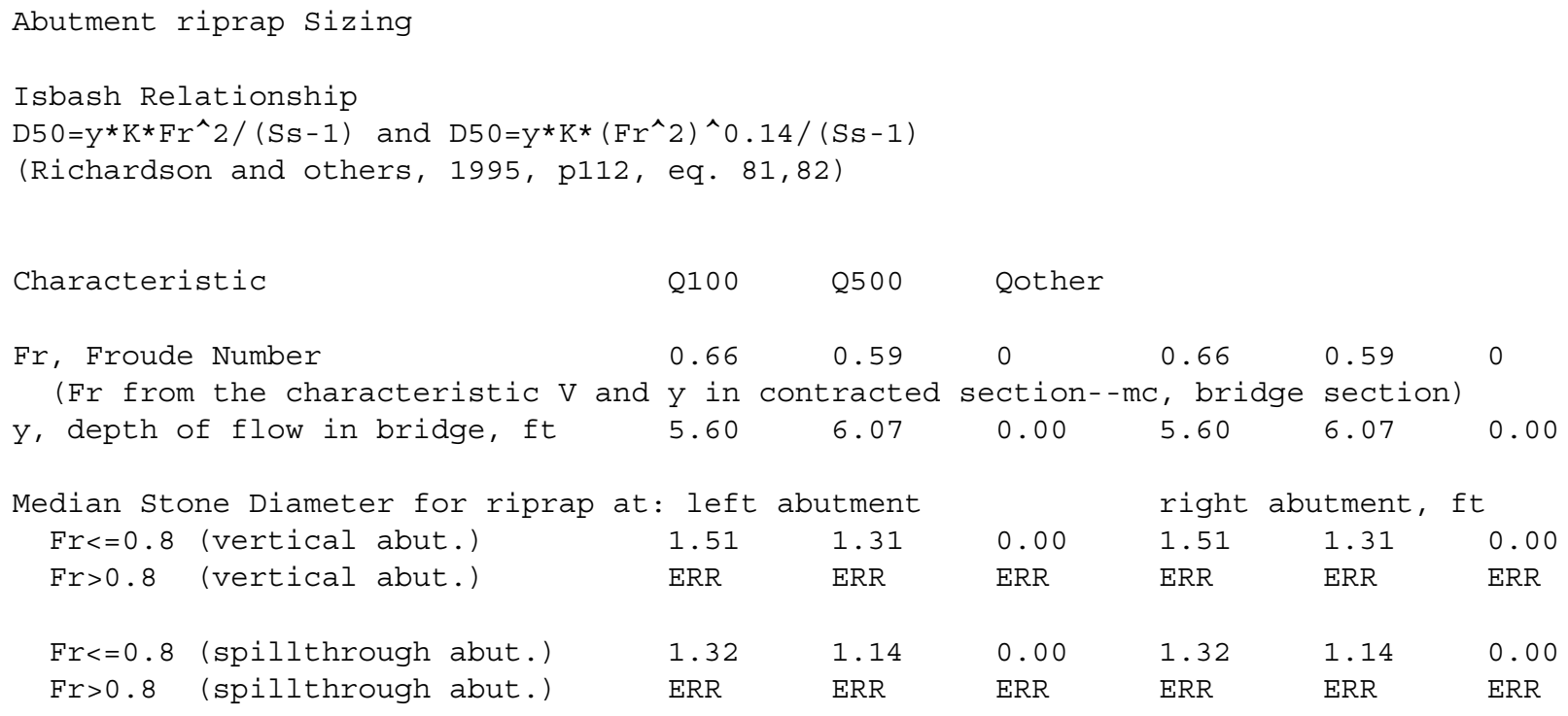

